\title{
Cytokines in the Germinal Center Niche
}

\author{
Christoph Jandl ${ }^{1,2}$ and Cecile King ${ }^{1,2, *}$ \\ 1 Garvan Institute of Medical Research, 384 Victoria Street, Darlinghurst, Sydney, NSW 2010, Australia; \\ c.jandl@garvan.org.au \\ 2 St Vincents Medical School, University of New South Wales, Sydney, NSW 2010, Australia \\ * Correspondence: c.king@garvan.org.au; Tel.: + 61-02-9295-8370
}

Academic Editor: Alexander Dent

Received: 17 November 2015; Accepted: 27 January 2016; Published: 5 February 2016

\begin{abstract}
Cytokines are small, secreted, glycoproteins that specifically affect the interactions and communications between cells. Cytokines are produced transiently and locally, acting in a paracrine or autocrine manner, and they are extremely potent, ligating high affinity cell surface receptors to elicit changes in gene expression and protein synthesis in the responding cell. Cytokines produced during the differentiation of $\mathrm{T}$ follicular helper ( $\mathrm{Tfh}$ ) cells and $\mathrm{B}$ cells within the germinal center (GC) niche play an important role in ensuring that the humoral immune response is robust, whilst retaining flexibility, during the generation of affinity matured antibodies. Cytokines produced by $B$ cells, antigen presenting cells and stromal cells are important for the differentiation of Tfh cells and Tfh cell produced cytokines act both in an autocrine fashion to firm Tfh cell differentiation and in a paracrine fashion to support the differentiation of memory B cells and plasma cells. In this review, we discuss the role of cytokines during the GC reaction with a particular focus on the influence of cytokines on Tfh cells.
\end{abstract}

Keywords: cytokines; germinal center; $\mathrm{T}$ follicular helper cells; interleukin

\section{Introduction}

The identification and analyses of soluble factors as regulators of lymphocyte functions were first studied over four decades ago [1,2]. It is now known that these soluble factors are cytokines that orchestrate the behavior of immune cells during immune responses to pathogens or following vaccination. The differentiation of antigen specific $B$ cells into high-affinity antibody secreting plasma cells and memory B cells that provide long-term humoral immunity occurs with the help of cytokines during the germinal center (GC) reaction. GCs are temporary, specialized structures that form at the site of follicular dendritic cells (FDCs) within the B cell follicles of secondary lymphoid tissues in response to infection or immunization [3,4]. Within the dynamic environment of the GC, processes occur that are driven by antigen and cytokines, including clonal expansion, somatic hypermutation, class switch recombination and selection of high-affinity antibody producing $B$ cells. The differentiation of affinity matured antibody producing GC B cells into plasma cells and memory B cells during the GC reaction is crucially dependent upon help from $\mathrm{CD} 4^{+} \mathrm{T}$ cells $[3,5,6]$.

The $\mathrm{CD}^{+} \mathrm{T}$ cells responsible for providing help to $\mathrm{B}$ cells during the GC reaction are termed $\mathrm{T}$ follicular helper (Tfh) cells [7-9]. Tfh cells localize to the B cell follicle [7-10] where they provide help to B cells through cell-to-cell interactions that enable the ligation of complementary T:B cell surface expressed molecules and through Tfh cell secreted cytokines. Cytokines secreted by Tfh cells and other cells within the GC niche influence both the growth, survival and differentiation of antibody forming B cells as well as the differentiation of Tfh cells in an autocrine manner [11-16] (Table 1). 
Table 1. Cytokines produced within the germinal center. Cytokines produced within the germinal center (GC) niche are listed; interleukin (IL), interferon-gamma (IFN- $\gamma$ ). Also listed are the cells producing these cytokines within the GC and their main function in this context, as well as the diseases in which they are implicated.

\begin{tabular}{|c|c|c|c|c|}
\hline Cytokine & Main Producers & Function in the GC & Disease & Reference \\
\hline IL-21 & Tfh cells & $\begin{array}{c}\text { GC B cell differentiation, affinity } \\
\text { maturation, Tfh cell } \\
\text { differentiation and function, }\end{array}$ & XSCID, RA, SLE, T1D & [13-22] \\
\hline IL-4 & Tfh cells & Ab class switching to IgG1, IgE & XSCID & {$[17,23]$} \\
\hline IFN- $\gamma$ & Tfh cells & $\mathrm{Ab}$ class switching to IgG2a & RA, SLE, T1D & {$[24,25]$} \\
\hline IL-10 & $\begin{array}{l}\text { human Tfh cells, } \\
\text { murine Tfr cells }\end{array}$ & $\begin{array}{l}\text { B cell proliferation, plasma cell } \\
\text { differentiation, Ab class } \\
\text { switching to IgG1 and IgG3 }\end{array}$ & $\begin{array}{c}\text { RA, SLE, Sjogren's } \\
\text { syndrome, Grave's disease }\end{array}$ & [26-31] \\
\hline IL-6 & FDCs, Plasmablasts & B cell and Tfh cell differentiation & RA, SLE & [32-34] \\
\hline IL-27 & unknown & $\begin{array}{l}\text { Tfh cell function, } \\
\text { IL-21 production }\end{array}$ & RA, SLE, T1D & [35-37] \\
\hline IL-2 & activated Th cells & $\begin{array}{l}\text { Treg differentiation, negative } \\
\text { regulator for Tfh lineage }\end{array}$ & EAE, T1D, Atherosclerosis & [38-42] \\
\hline IL-17 & Tfh like cells * & $\begin{array}{l}\text { B cell retention in GC, Tfh cell } \\
\text { localization to GC LZ }\end{array}$ & $\begin{array}{c}\text { RA, SLE, MS, } \\
\text { Sjogren's syndrome }\end{array}$ & [43-45] \\
\hline
\end{tabular}

${ }^{*}$ IL-17 production by T cells happens in dysregulated GCs during autoimmunity.

Defects in cytokine signaling have been implicated in immune disorders such as X-linked severe combined immunodeficiency (XSCID) and hypogammaglobulinaemia [17,22] (Table 1), whereas the deregulation of cytokine signaling can lead to autoimmune diseases such as systemic lupus erythematosus (SLE) and rheumatoid arthritis (RA) [21,46]. The major role of cytokines in the GC reaction to $\mathrm{T}$-dependent antigen has benefited from an increasing research focus over the past two decades. In this review, we provide an overview of the cytokines produced in the GC, the cells producing these cytokines, as well as their target cells and the signaling pathways involved, with a particular focus on Tfh cells.

\section{T Follicular Helper Cells, Cytokine Producers in the Germinal Center}

\subsection{Characterization of $T$ Follicular Helper Cells}

The presence of Tfh cells within the GC reaction ensures the survival and growth/expansion of antigen-specific B cells during the process of affinity maturation [7-9]. In the absence of T cells, GC form, but are not maintained $[47,48]$. The ability of activated CD4 ${ }^{+} \mathrm{T}$ cells to migrate from the $\mathrm{T}$ cell zone into the $\mathrm{B}$ cell follicle is mediated by the downregulation of $\mathrm{C}-\mathrm{C}$ chemokine receptor type 7 (CCR7) following TCR ligation that reduces tethering of T cells to the $\mathrm{T}$ cell zone where the ligands for CCR7 (the chemokines (C-C motif) ligand 19 (CCL19/ELC) and (C-C motif) ligand 21 (CCL21)) are expressed $[10,49]$. The reduction of CCR7 expression occurs in conjunction with increased expression of C-X-C chemokine receptor type 5 (CXCR5) [50,51]. CXCR5 is constitutively expressed on B cells where it is important for the formation of B cell follicles [52]. On CD4 ${ }^{+} \mathrm{T}$ cells, CXCR5 is expressed transiently upon TCR ligation [10] and is maintained at high levels on Tfh cells [7,8]. CXCR5 ${ }^{+}$CCR7 ${ }^{-} \mathrm{CD}^{+} \mathrm{T}$ cells migrate toward the ligand for CXCR5, namely chemokine (C-X-C Motif) Ligand 13 (CXCL13), which is produced by FDCs that mark the anatomical site where the GC reaction forms [49-51,53].

Apart from their location in the B cell follicle, Tfh cells are distinguished from other T helper cell subsets by the elevated expression of molecules that facilitate $\mathrm{T}$ and $\mathrm{B}$ cell collaboration. Direct interaction of CD40 on GC B cells and CD40L expressed by Tfh cells is indispensable for GC formation and plasma cell differentiation [54-57]. Tfh cells characteristically express high levels of ICOS, programmed cell death 1 (PD-1), the transcriptional repressor B cell lymphoma 6 (Bcl-6) as well 
as cytokines that influence B cell differentiation and antibody production, such as interleukin (IL)-21, IL-4 and interferon- $\gamma$ (IFN- $\gamma$ ) [24] (Figure 1 and Table 1). In contrast to murine Tfh cells, human Tfh cells have been found to also express the cytokine IL-10, which has important functions in human B cell differentiation [58]. The engagement of ICOS with its ligand (ICOS-L) expressed on antigen presenting cells (APCs) such as B cells, leads to the production of helper cytokines such as IL-4, IL-10 [11,59] and IL-21 [13]. The Tfh cell produced cytokine IL-21 [13,18] has been shown to be a potent inducer of plasma cell differentiation in both mice and humans in vitro $[17,60,61]$ and the importance of IL-21 for GC B cells is also well established $[15,16]$.

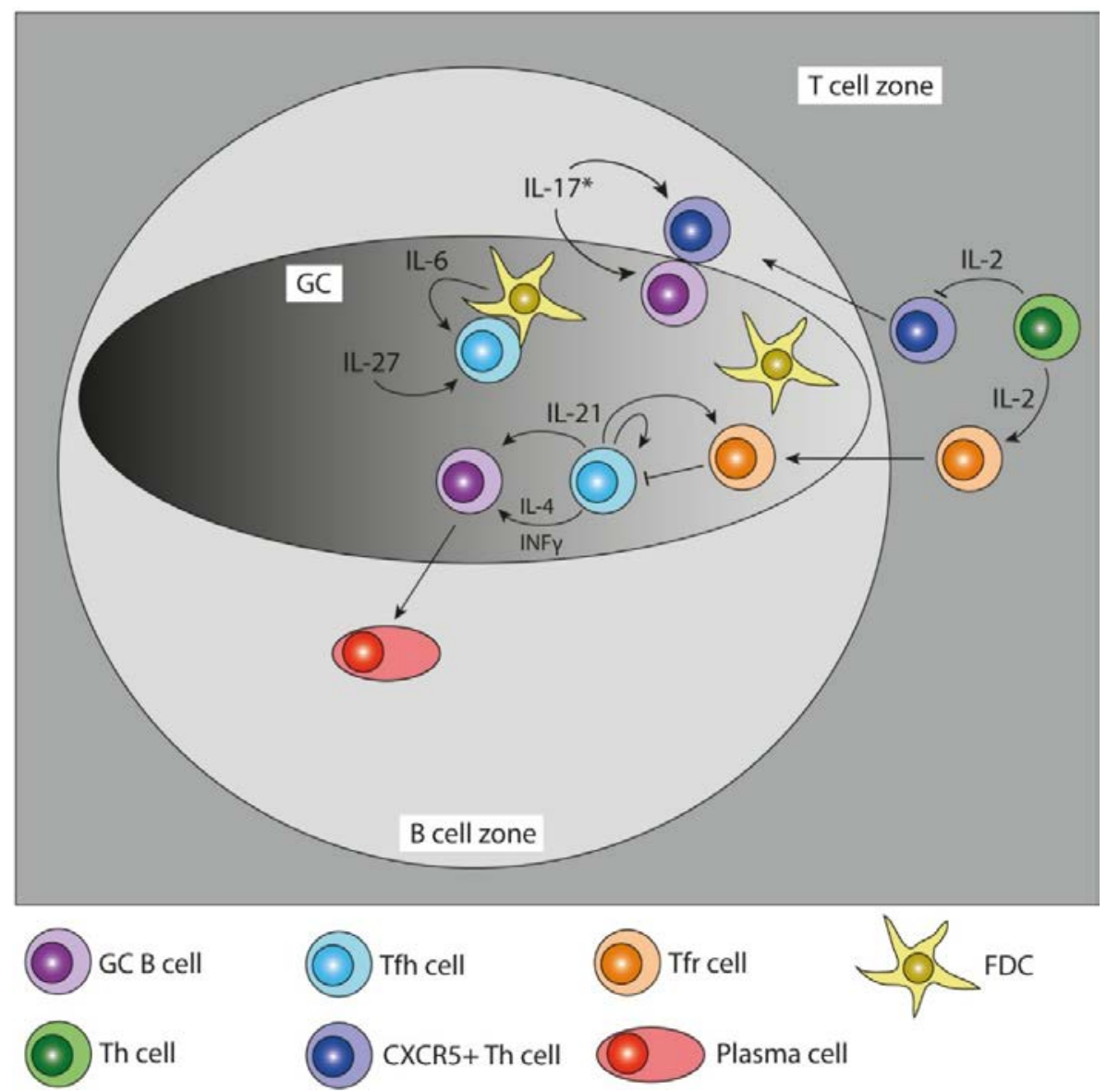

Figure 1. Cytokines in the germinal center (GC) reaction. Schematic diagram showing the cytokines that are important for the GC reaction and the action of these cytokines on different GC cell subsets. The relative importance of any given cytokine depends on the type of immune response during which it is expressed. Interleukin (IL), interferon-gamma (IFN- $\gamma$ ). *IL-17 production by T helper cells happens in dysregulated GCs during autoimmunity.

Microarray analyses of the Tfh cell transcriptome from both mice and humans revealed a unique gene expression profile that distinguished Tfh cells from other T helper cell subsets $[18,58,62,63]$. Tfh cells were observed to express the highest amounts of IL-21 as well as the intracellular adaptor protein SAP (SLAM-associating protein) and the transcription factor Bcl-6 [18,62,63]. Studies using the Roquin mouse model have shown a remarkably similar transcription profile in mouse and human Tfh cells, with the most highly expressed transcripts in Tfh cells (such as Il21, Cxcr5, CD84, Cxcl13, Bcl6 and Pdcd1, which encodes PD-1) detected in both organisms [62].

As the study of Tfh cells has progressed, the term Tfh cells has been used to describe $\mathrm{CD} 4^{+} \mathrm{T}$ cells that express CXCR5, indicating their B cell homing potential rather than localization to the GC or ability to support an affinity matured antibody response. By this definition, CXCR5hi PD1hi CD4 ${ }^{+}$ 
$\mathrm{T}$ cells have been detected in the blood in humans and mice $[7,8,64,65]$. Whilst the origin of these cells remains unknown, $\mathrm{CXCR} 5^{+} \mathrm{CD} 4^{+}$memory $\mathrm{T}$ cells have been observed to migrate into the $\mathrm{B}$ cell follicle in response to secondary antigen challenge indicating that the maintenance of CXCR5 expression on memory $\mathrm{CD}^{+} \mathrm{T}$ cells can support immunity [66-68].

\subsection{T Follicular Helper Cell Differentiation}

Studies collectively demonstrate that Tfh cell differentiation is a multistage process with key checkpoints regulating the formation, migration, expansion and survival of this $\mathrm{T}$ helper cell subset [24]. Upon recognition of peptide-MHC class II presented by dendritic cells (DCs) in the $\mathrm{T}$ cell zone, $\mathrm{CD} 4^{+} \mathrm{T}$ cells lose expression of CCR7 and upregulate CXCR5 in a Bcl-6 dependent manner $[7,8,69,70]$. The activated GC Tfh "precursors" interact with cognate B cells at the T-B border, and Ag-primed T helper cells with the highest affinity for antigen [71] are thought to maintain CXCR5 expression [50,51,72]. During this "second round" of cognate interaction, the primed CD4 ${ }^{+}$helper cells upregulate Bcl-6 expression and become fully differentiated Tfh cells $[69,70,73]$.

The differentiation, expansion and survival of Th cells are dependent upon signals from both DCs and B cells. Like other $\mathrm{CD} 4^{+} \mathrm{T}$ cell subsets, activation of Tfh cell "precursors" requires interaction with dendritic cells expressing peptide antigen in the context of MHC class II molecules. Detailed analyses of Tfh cell development revealed a broad upregulation of CXCR5, ICOS, Bcl-6, PD-1 and GL7 on CD4 ${ }^{+}$ T cells following early (day 2-3) interaction with dendritic cells (DC) [74-76]. As higher TCR affinity has been associated with a preference for Tfh cell differentiation [71], prolonged interactions with DCs during the first $24 \mathrm{~h}$ of priming leading to extended TCR and costimulatory receptor engagement as well as cytokine exposure, may bolster the Tfh differentiation program [77-79]. Tfh cells are able to develop in the absence of $B$ cells, provided that adequate stimulation is available to the $T$ cells in the form of peptide antigen-MHCII complexes on other APCs [79]. This finding may reflect the ability of B cells to act as a sufficient source of antigen for Tfh cells, but questioned whether B cells also provide any unique signals.

Although B cells are dispensable during the priming phase of $\mathrm{CD}^{+} \mathrm{T}$ cells, as well as in the initial steps of Tfh cell differentiation, they are of crucial importance for the maintenance and function of Tfh cells during the GC reaction. B cells provide an important function in supporting the expansion/survival of $\mathrm{CD}^{+} \mathrm{T}$ cells [80]. Notably, B cells support the maintenance of the Tfh cell phenotype as Bcl-6 expression and Tfh cell commitment is interrupted in the absence of T-B cell interactions [74]. Interaction with antigen-presenting B cells on the T-B border leads to the SAP-mediated secondary upregulation of Bcl- 6 stabilizing the expression of CXCR5 on CD4 ${ }^{+} \mathrm{T}$ cells, who are then able to migrate into the GC and fully differentiate into Tfh cells [81-83]. Signals from ICOSL expressed on activated B cells promote persistent Tfh cell motility thus aiding Tfh migration in the B cell follicle [84].

Tfh cells differentiate under different contexts and thus must be able to assimilate a variety of input signals and this is reflected in the contribution of several transcription factors that are important for Tfh cell differentiation. T cell intrinsic Bcl-6 activity is required for Tfh cell development and GC responses to T-dependent antigen $[69,70,85]$. Bcl- 6 can inhibit the differentiation of other (non-Tfh) $\mathrm{CD} 4^{+} \mathrm{T}$ cell subsets and has been shown to antagonize transcription factors important for Th1, Th2 and Th17 differentiation [69,70]. Both IL-6 and IL-21 have been shown to upregulate the expression of Bcl-6 $[14,86]$. Critical molecules for T-B cell interactions such as SAP, CD40L, PD-1, ICOS and CXCL13 are induced by the Tfh cell master transcription factor Bcl-6 [87]. Whilst Bcl-6 expression is high in Tfh cells, the Bcl- 6 antagonist Blimp- 1 is most highly expressed by other $\mathrm{CD} 4^{+} \mathrm{T}$ cell subsets $[85,88,89]$. Another transcription factor which has been shown to be important for optimal Tfh cell numbers is c-Maf, which induces IL-21 production in a ICOS-dependent manner [90] by directly binding the IL-21 promoter [91]. In addition, mice deficient in the transcription factor IRF4 (Irf4 ${ }^{-/}$) are unable to upregulate Bcl-6, CXCR5 and ICOS due to an T cell intrinsic defect and thereby fail to generate Tfh cells [92,93]. IRF4 contributes to Tfh cell differentiation, but this role is not Tfh cell specific, 
since Irf4 $4^{-/-}$mice also exhibit defects in the differentiation of Th2, Th9 and Th17 cell subsets [94-96]. Furthermore, an $\mathrm{CD}_{4}^{+} \mathrm{T}$ cell intrinsic dependency on NF-kB-signaling for Th2 and Tfh cell induction in response to T-cell dependent $\mathrm{Ag}$ was found in adoptive transfer experiments with $\mathrm{NF- \kappa B1}-1-$ $\mathrm{CD}^{+} \mathrm{T}$ cells [97]. NF- $\mathrm{kB1}$ deficiency was shown to have detrimental effects on the production of Th2 cytokines IL-4 and IL-13 and even more notably suppressed the induction of CXCR5, whereas expression of other Tfh cell markers such as Bcl-6, IL-21, CXCR4, OX40 mRNA as well as PD-1 protein was not impaired [97]. The importance of signaling through the trans-membrane receptor Notch for Tfh differentiation as well as IL-4 secretion by $\mathrm{CD}_{4}^{+} \mathrm{T}$ cells has been shown in mice with a $\mathrm{CD} 4^{+} \mathrm{T}$ cell specific deletion in both Notch1 and Notch2 $\left(\mathrm{N}_{\mathrm{NN}}{ }^{-/-}\right)$[98]. Notch-signaling is suggested to influence Tfh cell differentiation through its impact on the balance of Bcl6 and Blimp1 mRNA expression [98].

Although Bcl-6 is critical for the differentiation of Tfh cells, it is not exclusively expressed in Tfh cells. More recently, a Tfh specific transcription factor has been identified that drives the differentiation program of Tfh cells. Achaete-scute homologue 2 (Ascl2)—a basic helix-loop-helix (bHLH) transcription factor was selectively upregulated in Tfh cells. Ectopic expression of Ascl2 upregulated CXCR5 (but not Bcl-6) and downregulated CCR7 expression in T cells in vitro, as well as both accelerating the migration of $\mathrm{T}$ cells to the follicles and Tfh cell development in mice [99].

\subsection{T Follicular Regulatory Cells}

Regulatory $\mathrm{T}$ cells (Tregs) that could suppress the humoral immune response $[1,100]$ and $\mathrm{CD} 25^{+} \mathrm{T}$ helper cells that localize to the GC $[101,102]$ have been described over the past four decades. However, it was more recently that a population of Tregs with follicular homing ability was located within the GC. CXCR5hi PD1hi FoxP3 ${ }^{+}$Tregs within the GC were named T follicular regulatory (Tfr) cells [31,103,104]. Foxp $^{+}$Tfr cells originate from natural (thymus-derived) Treg cells (nTregs) and acquire features of Tfh cells, such as expression of CXCR5 [10,31] and high expression of PD-1 [65]; however, unlike Tfh cells, they lack expression of CD40L, IL-4 and IL-21 [31,103,104].

Tfr cells also possess an activated Treg phenotype, expressing high levels of GITR, CTLA-4 and IL-10 [31,103] (Table 1) and the transcription factor Helios, reported to be expressed by thymic nTregs but not by "inducible" Tregs (iTregs), which are induced to express FoxP3 following antigen stimulation in the periphery from FoxP3 ${ }^{-} \mathrm{CD}^{+} \mathrm{T}$ cells $[105,106]$. Adoptive transfer of FoxP3 ${ }^{+}$Treg cells into congenic recipient mice demonstrated that Tfr cells originate from nTregs and not from extrathymic $\mathrm{CD}^{+} \mathrm{T}$ cell populations such as $\left(\mathrm{FoxP}^{-}\right) \mathrm{Tfh}$ cells $[31,103]$. Tfr cells exhibit a negative regulatory function on both Tfh cells and GC B cells, as well as suppressing antigen-specific antibody production $[31,107,108]$. By contrast, a recent study showed that Tfr cells reduce the levels of IL-2 by utilizing IL-2 within the GC [109]. Since IL-2 inhibits Tfh cells [110], the utilization of IL-2 by Tfr cells may have a positive regulating effect on the GC reaction. Taken together, these findings suggest that Tfr cells may operate to balance the magnitude of the GC output, but aspects of their function remain incompletely understood.

\section{Cytokine Signaling within the Germinal Center}

The cytokine environment is determined by several factors including the form of immunogen and the type of secondary lymphoid tissue. Studies have provided evidence for an array of cytokines produced in the GC environment and by Tfh cells as they migrate into the GC. The earliest evidence for cytokine production within the B cell follicle and GC came from in situ hybridization studies. These studies showed the presence of IL-4, IL-5, IFN- $\gamma$ and IL-2 to varying degrees within human low-grade lymphoma tissue [111,112] and in the lymph nodes (LN) of HIV infected individuals [113]. In mice, cytokine detection in the B cell follicle after immunization has provided variable results, including the detection of cytokine transcripts within the paracortex [114], whereas other studies have been unable to detect IL-4, IL-5 or IFN- $\gamma$ in the LN of immunized mice [115]. Early studies on germinal center T cells isolated from human tonsil based upon expression of CD57 detected IL2, IL4, IL10, IFN $\gamma$ 
and TNF $\alpha$ mRNA in low concentrations [116,117]. In addition to GC T cells, a strong production of IL1 $\beta$ mRNA and protein was observed in a small percentage of FDCs [117].

Improved reagents and methods to detect cytokines intracellularly by flow cytometry have facilitated the identification of cytokine producing cells (Figure 1 and Table 1). The advent of cytokine reporter mice that enable visualization of the transcription and production of cytokines in individual cells has greatly advanced our understanding of what cells produce which cytokines and when and where they do it.

\subsection{Cytokine Reporter Mice}

Recently, several groups have analyzed the relationship between IL-4-producing Tfh cells using IL-4-reporter mice $[23,118,119]$. These transgenic mice either express a single reporter gene marking cells that express IL4 mRNA (IL-4-competent cells) or a combination of two reporter genes marking cells that express IL4 mRNA as well as cells that actually secrete the IL-4 protein. The analyses of $\mathrm{T}$ helper cell differentiation during infection of IL-4-reporter mice confirmed previous reports showing that Tfh cells can express IL-4 $[9,51,61,120]$ and demonstrated that the majority of IL-4 production is localized to the B cell follicle $[23,118]$.

During Leishmania major infection studies of the dual IL-4 reporter mice, Tfh cells producing IL-4 could be distinguished from IL-4-producing Th2 cells by their high expression of CXCR5 and IL-21 [23]. The use of an IFN $\gamma$ - reporter mouse crossed to the IL- 4 reporter, enabled the detection of both IL-4 and IFN $\gamma$ - producing GC T cells [23]. The isolation of T cell-B cell conjugates from the draining lymph node demonstrated that IgG1-producing B cells made contact with IL-4-producing T cells whereas IgG2a-producing B cells made contact with IFN $\gamma$-producing $\mathrm{T}$ cells [23]. IL-4-producing $\mathrm{T}$ cells were found conjugated to GC B cells expressing high levels of AID, with evidence of somatic hypermutation [23] demonstrating that Tfh derived cytokines direct the production of different antibody isotypes and the process of affinity maturation of antibodies in the responding B cells.

More recently, an IL-21 reporter mouse generated by introducing sequence encoding green fluorescent protein (GFP) into the Il21 locus has enabled the identification and analyses of IL-21-GFP expressing $\mathrm{CD}^{+}{ }^{+} \mathrm{CXCR} 5^{+} \mathrm{PD}-1^{+}$Tfh cells. Following immunization with NP-KLH in aluminum hydroxide (alum), IL-21-GFP expression was restricted to a proportion of cells with a Tfh cell phenotype and IL-21-GFP ${ }^{+}$Tfh cells coexpressed several cytokines, including IFN- $\gamma$, IL-2 and IL-4 [121]. IL-21-GFP ${ }^{+}$Th cells gave rise to transferrable memory cells with plasticity, that differentiated after antigen recall into both conventional effector helper T cells and Tfh cells indicating that Tfh cells retained the flexibility to be recruited into other helper $\mathrm{T}$ cell subsets [121].

Further evidence for the remarkable plasticity of Th cell subsets was found when FoxP3 ${ }^{+} \mathrm{CD} 4^{+}$ $\mathrm{T}$ cells from FoxP3 ${ }^{\mathrm{EGFP}}$ mice, which express GFP under the control of the FoxP3 promoter, were transferred into T cell deficient $C D 3 \varepsilon^{-/-}$mice [122]. In the Peyer's patches (PP) of the small intestine, the transferred cells lost their FoxP3 expression and differentiated into Tfh cells, promoting GC formation and IgA expression [122]. These findings further supported the notion that distinct microenvironmental cues can promote the differentiation of Tfh cells from other Th cell subsets.

\subsection{IL-21-IL6, Functional Redundancies}

Differentiation of Tfh cells relies upon signal integration from several inputs including cytokines such as IL-21 and IL-6 [32,33] (Figure 1 and Table 1). Both IL-21 and IL-6 play a role in the generation of a GC reaction of optimal magnitude. Studies have shown that mice made genetically deficient in either the receptor for IL-21 (Il21r-/- mice), IL-21 (Il21 ${ }^{-/-}$mice) or IL-6 (Il6 ${ }^{-/-}$mice) have GC reactions of reduced magnitude $[13,14,123]$. $I l 21^{-/-}, I l 21 r^{-/-}$and $I l 6^{-/-}$mice have also been reported to exhibit decreased Tfh cell numbers after immunization with T-dependent antigen $[13,14]$. However, the influence of IL-21 on Tfh cells has been context dependent; influenced by the immunogen/adjuvant, whether the response is primary or secondary and also influenced by the surface markers used to define Tfh cells $[13,15,16,68,124]$. Importantly, IL-6 and IL-21 appear to have redundant functions for 
Tfh cell differentiation. Whilst the absence of either IL-6 or IL-21 alone only has a modest impact, [73], eliminating signals from both cytokines severely diminished the percentages of Tfh cells following infection [32,33].

IL-6 expressed by plasmablasts can act as a signal driving Tfh cell formation in humans [125], and stromal cells in the B cell follicle such as FDCs have also been identified as a potential source of IL-6 $[123,126]$ (Figure 1). Although $I l 21 r^{-/-}$mice did not show a difference in numbers of either mature or immature B cells in comparison to wild type mice [17], lower levels of IgG1 and higher levels of IgE could be detected in naive $I l 21 r^{-/-}$mice compared with wild-type mice $[17,127,128]$.

Both IL-6 and IL-21 signal through the JAK-STAT pathway inducing activation of janus kinase (JAK)1 as well as JAK3, which in turn leads to the activation of signal transducer and activator of transcription (STAT)1 and STAT3 [86,129-131]. STATs are DNA-binding transcription factors that influence gene transcription by binding DNA target sites as homodimers or heterodimers and can form transcriptional complexes with non-STAT transcription factors [132]. The observation that both IL-21 and IL-6 activate STAT1 and STAT3 upon binding to their respective receptors may underpin the observed functional overlap between these two cytokines in Tfh cell differentiation $[32,33,86,127,133]$.

STAT1 activation by IL-6 signaling has been shown to be critical for Bcl-6 induction and subsequent differentiation of Tfh cells [86]. Whether IL-21 mediated STAT1 signaling is important for the Tfh differentiation program remains unknown. The activation of STAT3 is required for the production of IL-21 by $\mathrm{CD}^{+}{ }^{+} \mathrm{T}$ cells from mice and humans after stimulation with IL-6, IL-21, IL-23 and IL-27 $[14,36,134]$ (Table 1). Additionally, it was shown that STAT1 and STAT3 cooperate in promoting Tfh differentiation in response to IL-6 [86]. The importance of IL-21 mediated STAT3 signaling for $B$ cells has been demonstrated in human B cells in vitro [129] and in murine plasma cells in vivo [135].

Although STAT3 can bind the Bcl6 gene and upregulate its expression, STAT3 is also a strong inducer of Blimp-1 expression in B cells $[92,129,136]$. By contrast, constitutive expression of Blimp-1 suppresses Bcl-6 expression in $\mathrm{CD}^{+}{ }^{+} \mathrm{T}$ cells, leading to defects in Tfh cell differentiation [85]. The deletion of Blimp-1 from $\mathrm{CD}^{+}{ }^{+} \mathrm{T}$ cells leads to augmented Tfh cell formation in response to viral infection as this transcription factor directly suppresses Bcl-6 expression [74,85].

Expression of Bcl-6 is upregulated by IL- 6 as well as IL-21 in an autocrine manner in T cells $[69,70,137]$. Furthermore, it has been shown that IL-6 is not only able to function in place of IL-21 but it can also induce the production of IL-21 and influence Tfh cell differentiation in this way [138]. The roles of IL-6 and IL-21 on both B cells and Tfh cells during the GC reaction may reflect the dual ability of IL-6 and IL-21 to upregulate critical GC transcription factors such as Bcl-6 in both B and T cells. Similar to IL-6 and IL-21, IL-27 signaling involves the activation of Jak1, STAT1, and STAT3 [139]. IL-27 has also been shown to be important for the function of Tfh cells and for affinity matured antibody responses [36] (Figure 1 and Table 1). IL-27 signaling to T cells results in the production of IL-21 and improves Tfh cell survival in a STAT3-dependent manner [36]. Recent studies have built on our knowledge base to explain the important contribution of both IL-6 and IL-21 to Tfh cell differentiation and the GC reaction. However, important questions remain including the timing of the production of IL-6, IL-21 and IL-27 during Tfh differentiation and the GC reaction in different contexts of infection and immunisation.

\subsection{IL-21-IL-2, Antagonizing Functions}

The evolution of the genes that encode the known array of cytokines and receptor complexes involved multiple duplications from a smaller set of genes, followed by the divergence of sequence and product function [140]. The cytokines IL-2 and IL-21 are encoded on adjacent genes on chromosome 3 in mice and chromosome 4 in humans and are thought to have arisen by gene duplication. Both IL-2 and IL-21 are secreted by CD4 $4^{+} \mathrm{T}$ cells, but studies show that they exert opposing functions in the differentiation and function of $\mathrm{CD} 4^{+} \mathrm{T}$ cell subsets [13,141-144]. Whereas IL-2 is an important survival factor for forkhead family transcription factor (FoxP3) expressing Tregs that are vital for the regulation of immune responses in both mice and humans [141,142,145,146], IL-21 can inhibit the expansion 
and function of FoxP3 ${ }^{+}$Tregs $[143,147,148]$. IL-21 is one of the most highly expressed genes in Il2-/mice [149], indicating that regulation of IL-21 or IL-21-producing Th cells is an important role of Tregs.

Recent studies have contributed significantly to our appreciation of how the interplay between IL-2 and IL-21 can shape the outcome of antibody responses. Tregs expand to a greater extent in $I l 21^{-/-}$mice than in WT mice after immunization and treatment with anti-CD28 mAbs [13]. IL-21 signaling can inhibit the expansion of Tregs both in vitro [143] as well as after infection with LCMV [144]. The negative effect of IL-21 on Treg homeostasis and suppressor function has been proposed to be achieved by IL-21 mediated down regulation of FoxP3 expression on Tregs and by inhibiting IL-2 production from activated $\mathrm{T}$ cells ( $\mathrm{T}$ conventional cells), thereby limiting its availability as a growth and survival factor for Tregs [143,147,150-152].

Tregs are dependent upon IL-2 for their growth and survival and the size of the Treg population is directly correlated with the amount of bioavailable IL-2 [38,39] (Table 1). By contrast, IL-2 has an inhibitory effect on Tfh cell differentiation, thereby counteracting one of the most important functions of IL-21 $[110,153,154]$ (Table 1). IL-2 induces Blimp-1 expression in CD4 ${ }^{+} \mathrm{T}$ cells, and administration of IL-2 in an influenza virus infection model leads to reduced Tfh cell numbers as well as less antibody production, thereby suggesting an antagonistic role for IL-2 and IL-21 on Tfh cells [110]. As IL-2 mainly signals through STAT5, its limiting effect on Tfh cell formation has been suggested to operate through the suppression of Bcl-6 through STAT5 mediated upregulation of Blimp-1 [42,153]. One recent study was also able to show increased Tfr cell numbers as well as decreased Tfh cell numbers in the absence of IL-21 signaling in lupus-prone BXD2 mice [155], further highlighting the important role of IL-21 on $\mathrm{CD}^{+} \mathrm{T}$ cells in the GC reaction. Two mechanisms for the negative effect of IL-2 on Tfh cells have been proposed. Firstly, IL-2 mediated activation of STAT5 leads to activation of the transcriptional repressor Blimp-1, which, in turn, leads to the repression of the transcription factor Bcl-6, thereby negatively regulating Tfh cell differentiation and proliferation [153,154]. Secondly, STAT5, activated by IL-2, is able to displace STAT3 bound to the Bcl-6 promoter, adversely influencing Tfh cell formation in this manner [42].

\subsection{IL-21-IL-4, Collaborative Functions}

As discussed earlier, while IL-21 can be considered the signature cytokine of the Tfh cell lineage, it has been demonstrated that these cells also secrete other cytokines, such as IL-4 [23,121]. The expression of IL-4 by Tfh cells is regulated by the transcription factor Batf [156]. Together with IRF4 and in concert with STAT3 and STAT6, Batf binds to the CNS2 region of the Il4 locus and thereby promotes IL-4 production in Tfh cells [156]. Apart from its role in IL-4 production, Batf has also been shown to control expression of the transcription factors Bcl-6 and c-Maf leading to impaired Th17 and Tfh cell development in Batf ${ }^{-/}$mice $[157,158]$. Although the effect of IL-21 on the differentiation of naïve human B cells into antibody secreting cells could be decreased by IL-4 through its antagonizing effect on IL-21 induced Blimp-1 expression [60,61], the stimulation of human B cells in culture with both IL-4 and IL-21 resulted in increased production of IgE $[159,160]$. The ability of IL-21 to promote IgE production from human $B$ cells in vitro stands in contrast to the observation of elevated $\operatorname{IgE}$ in humans with loss of function mutations in IL21R and in both $I l 21 r^{-/-}$and $I l 21^{-/-}$mice $[16,17,161]$.

Paradoxically, despite reduced IL-4 detected in sera and reduced production of IgG1 after infection, Il21r $-/$ - mice harbor increased amounts of the antibody isotype IgE [17]. The mechanism for the inhibitory effect of IL-21 on IgE has been explored in several studies. IL-21 has been shown to down-regulate IgE production from IL-4-stimulated B cells through the inhibition of germ line $\mathrm{C}$ (epsilon) transcription [162]. In addition, the transcriptional repressor Bcl-6 negatively regulates the I $\varepsilon$ promoter [163] and, in this manner, IL-21 may negatively regulate IgE production by increasing the expression of Bcl-6 in B cells [15]. More recently, Il21r $r^{-/}$B cells and T cells were observed to exhibit reduced surface expression of IL-4Ra, which was accompanied by reduced production of soluble IL-4Ra [124], sIL-4Ra is known to bind IL-4 and reduce IgE levels in mice, but whether reduced sIL-4Ra contributes to the increased IgE observed in $I l 21 r^{-/-}$mice remains unknown [124]. 
The critical dual role of IL-4 and IL-21 in antibody production was highlighted in mice lacking both IL-4 and IL-21R (Il4-/- Il21r-/-) that exhibited pan-hypogammaglobulinaemia [17]. In addition to the lack of IgG isotypes, the double knock-out mice lacked the increased amounts of IgE observed in $I l 21 r^{-/-}$mice, confirming the IL-4 dependency of the elevated IgE in the absence of IL-21:IL-21R signaling [17]. The B cell phenotype shown by $I l 4^{-/} I l 21 r^{-/-}$mice was similar to human patients with XSCID, leading to the hypothesis that this disease could be caused by the combined loss of signaling mediated by these two cytokines [17].

\subsection{Interferon- $\gamma$, A Non-Canonical Cytokine Expressed by Tfh Cells}

Expression of IFN- $\gamma$ by Th cells is important for IgG2a class switching of murine B cells. Low expression of IFN- $\gamma$ by CXCR5hi Tfh cells could be detected in human tonsils [70,164], as well as mice immunized with sheep red blood cells $[23,85,121]$. By contrast, in comparison to CD4 ${ }^{+} \mathrm{T}_{\text {cells }}$ that express intermediate levels of CXCR5, a substantial increase of IFN- $\gamma$ production by Tfh cells has been observed during viral infection [165]. A close relationship between Tfh cells and IFN- $\gamma$ has been recently demonstrated in lupus-prone sanroque mice. Elevated expression of IFN- $\gamma$ present in the GC of sanroque mice leads to increased numbers of pathogenic Tfh cells and autoimmune antibody responses, suggesting a role for IFN- $\gamma$ for Tfh cell formation [166]. Developing Tfh cells have been shown to repress IFN- $\gamma$ expression through the upregulation of the transcriptional repressor Bcl-6 [70], which is consistent with the quantitatively low expression of GATA3 and T-bet in Tfh cells in comparison to other $\mathrm{CD}^{+} \mathrm{T}$ cell subsets $[23,85,165]$, supporting the idea that low levels of IFN- $\gamma$ expressed by Tfh cells are sufficient for IgG2a class switching [24].

\subsection{IL-21-IL-10, Differential Functions in Humans and Mice}

Interleukin-10 has been shown to have multiple effects on various types of immune cells, most notably it functions as a survival, proliferation and differentiation factor for B cells [26,27,167]. Before IL-21 was described, IL-10 had been considered the most potent inducer of human plasma cell differentiation $[28,29,61]$. IL-10 promotes immunoglobulin class switching to IgG1 and IgG3, and is a strong inducer of immunoglobulin secretion [28]. The production of IL-10 by T cells follows stimulation through the T cell receptor (TCR), CD28 and ICOS $[29,168]$, and there is a direct relationship between ICOS expression by CD4 ${ }^{+}$T cells and the amount of IL-10 produced $[168,169]$.

Whilst IL-10 is a strong inducer of plasma cell differentiation in humans, it is associated with both immunosuppressive [170] and proinflammatory effects in mice [171]. By contrast to the effect of IL-10 on B cells, IL-10 has a negative effect on Tfh cell differentiation in mice. At least two different mechanisms have been demonstrated: First, B cells co-cultured with Tfh cells deficient for the IL-10R subunit $\beta\left(I l 10 \mathrm{rb}^{-/-}\right)$showed increased antibody responses in vitro [172], demonstrating Tfh cell intrinsic inhibitory effect of IL-10. Secondly, the inability of DCs in $I l 10 \mathrm{rb}^{-/-}$mice to respond to IL-10 resulted in higher levels of IL-6, IL-12 and IL-23 in these mice, which resulted in higher Tfh cell numbers [172]. Additionally, the expression of IL-17 and IL-21 was increased in the IL-10R deficient mice, which suggests a regulatory role of IL-10 on both number and function of Tfh cells in mice [172]. The fact that IL-10 negatively regulates Tfh cells both in normal and autoimmune settings [172,173] might explain one of the mechanisms of Tfr cell mediated regulation of Tfh cells, since Tfr cells have been shown to express Il10 mRNA [31] (Figure 1). How exactly IL-10 negatively regulates Tfh cells in mice is still unknown, but IL-10 mediated induction of Blimp-1 has been suggested as one possible mechanism [174]. An important source of IL-10 may be Tregs under certain settings, but the finding that $I l 2^{-/}$mice that are deficient in IL-2-dependent FoxP3 ${ }^{+}$Tregs have significantly greater amounts of IL-10 in serum compared with WT mice indicates that IL-10 is produced by a variety of cells and further illustrates the complex role of IL-10 during immune responses [149]. 


\subsection{IL-21-IL-17, Complementing Functions in Autoimmune Disease}

A potent role for IL-17 in the production of self-reactive $\mathrm{Ab}$ and the formation of GCs in autoimmune disease has been established $[43,175,176]$. Although IL-17 is not produced by human tonsilar Tfh cells or murine Tfh cells induced by immunization [70], elevated levels of this cytokine in systemic autoimmunity prone BXD2 mice leads to spontaneous formation of GCs [43]. The IL-17 receptor (IL-17RA) was shown to be highly expressed by both Tfh cells and GC B cells in BXD2 mice [43,45] (Figure 1 and Table 1). The aberrant production of IL-17 in the context of the GC leads to the upregulated expression of the genes Rsg13 and Rsg16 in B cells of BXD2 mice, both of which have been shown to inhibit CXCR4-CXCL12 signaling and therefore B cell migration [177,178]. A more recent study suggested that IL-17 signaling is of high importance for optimal localization of Tfh cells into the light zone (LZ) of the GC in BXD2 mice [45]. Although IL-17 is not needed for Tfh cell development per se, it complements the effects of IL-21 since the loss of either cytokine abrogates development of autoimmune GCs in BXD2 mice [45]. T helper 17 (Th17) cells producing IL-17 are highly proinflammatory effector T cells associated with a number of autoimmune diseases [179], and they can provide help to B cells and mediate class switching to IgG1 and IgG2b as well as to a lesser extent to IgG2a and IgG3 [180]. Th17 cells have also been shown to mediate GC formation [180] and even acquire a Tfh-like phenotype in the environment of the payers' patches of the small intestine [181]. Further evidence for IL-17 producing Tfh-like cells was found in $R O R \gamma t^{-/-}$mice [182]. However, whether these cells constitute a genuine new subpopulation of Tfh cells or provide another example of the remarkable plasticity between Th cell subsets within distinct microenvironments remains unknown.

\section{Roles for Germinal Center Cytokine Signaling in Disease}

Not only are GC reactions important for humoral immune responses against pathogens and long lasting immunological memory, but defects in regulating GC cytokines can also lead to autoimmune disease or immune deficiencies. Mutations in the in the IL2RG gene, encoding the $\gamma c$ through which signaling for the cytokines IL-2, IL-4, IL-7, IL-9, IL-15 and IL-21 occurs, cause the disease XSCID in humans $[19,131,183]$. This disease is characterized by the absence of $\mathrm{T}$ cells and NK cells, and although B cell numbers in patients with XSCID are normal, the B cells seem to be unable to perform their proper function [184]. IL-21 imparts both autocrine and paracrine effects on lymphocytes influencing survival and differentiation [185-187] and contributes to the development of inflammatory and autoimmune diseases [186] (Table 1). In humans, loss-of-function mutations in IL21 or IL21R cause a primary immunodeficiency syndrome. These patients exhibit defects in antibody production, $\mathrm{T}$ cell and NK cell functions and an increased susceptibility to chronic infections and gastrointestinal inflammation [161,188,189].

Genome-wide association studies have identified the locus encoding $I l 21$ and $I l 2$ as a risk factor for autoimmune diseases such as systemic lupus erythematosus (SLE), type 1 diabetes, inflammatory bowel disease, coeliac disease, psoriasis and psoriatic arthritis [20,21,190-192]. Dysregulated Tfh cells, including increased Tfh cell numbers and production of IL-21, have been implicated in a number of autoimmune diseases [20,21,190-193].

The BXSB-Yaa mouse model for SLE is characterized by an accumulation of IL-21 expressing Tfh cells [22,194]. These mice develop severe SLE symptoms such as spontaneous GC formation, increased autoantibody production, hypergammaglobulinemia and glomerulonephritis [136,195]. Crossing the BXSB-Yaa mice with a $I l 21 r^{-/-}$mouse line alleviated disease symptoms, improved mortality and resulted in a significant reduction in the production of autoreactive antibodies [22,194]. The benefit of the therapeutic approach of blocking IL-21 signaling in autoimmune settings has been demonstrated in several studies [22,196-198]. In addition to IL-21, therapeutic targeting of other GC cytokines has a beneficial effect on mouse models of Lupus. Blockade of the interaction of IL-4 with its receptor by antibody treatment or of its downstream signaling by inactivation of the Stat6 gene ameliorates glomerulosclerosis as well as delaying the development of end-stage renal disease $[199,200]$. 
Elevated levels of IL-21 protein and mRNA have been detected in human patients suffering from RA, a chronic autoimmune disease characterized by inflammation of synovial joints and the expression of autoreactive antibodies leading to the destruction of bone and cartilage [196]. Increased frequencies of circulating Tfh cells have been detected in RA patients and clinical studies showed that the elevated levels of IL-21 in these patients decreases following treatment, which correlates with improvement of disease activity $[46,201,202]$. Additionally, observations made in mouse models of RA suggest an essential role for IL-21 in disease development [203]. Similar to IL-21, patients with RA have high synovial levels of IL-6 [34] and therapeutically targeting IL-6 receptors has been shown to be beneficial for many RA patients [204].

Taken together, these studies demonstrate that cytokines have emerged as important prognostic factors in human disease, and the therapeutic targeting of cytokines produced within the GC niche has proved beneficial in the treatment of antibody mediated autoimmune diseases.

\section{Conclusions}

In order to respond to a variety of pathogens, the immune response must be agile and this is reflected in the context dependent differences observed in the GC reaction. Cytokines operate across short (cell-cell) distances, acting in an autocrine and/or paracrine manner. The cytokine milieu in the GC is dependent upon the type of secondary lymphoid tissue, the cell types that form the GC locus and those that migrate there to participate in the GC reaction. Tfh cells begin their process of differentiation in the $\mathrm{T}$ cell zone of secondary lymphoid tissues, where cytokines produced by $\mathrm{T}$ cells and antigen-presenting cells are prominent. As Tfh cells migrate into the B cell follicle and GC, they encounter cytokines produced by other Tfh cells, B cells and FDCs. Antigen-specific B cells, in turn, begin the process of class switch in response to $\mathrm{T}$ cell produced cytokines prior to their migration into the GC, where they encounter cytokines produced by Tfh cells and FDCs that influence GC B cell proliferation, survival and differentiation.

Recent advances in Tfh cell biology have focused our attention on cytokines in the GC niche. These advances have been made possible by state of the art techniques such as intravital microscopy and cytokine-reporter mice that enable the detection and tracking of small numbers of cells during the GC reaction. However, despite such advances, many questions remain unanswered. They include the kinetics of cytokine production in the context of Tfh cell and GC B cell differentiation. GC cytokines use both overlapping and discrete signaling pathways to elicit their effects on responding cells. How multiple cytokines signaling through common pathways influence cell differentiation remains incompletely understood. The relative contributions of cytokine signaling components to the behavior and differentiation of cells that participate in the GC reaction, including the roles of individual STAT proteins in both homodimeric and heterodimeric forms, remains an important unanswered question.

Acknowledgments: This work was supported by project grants 1029942 and 1087408 from the National Health and Medical Research Council of Australia and by the Rebecca L. Cooper Research Foundation.

Conflicts of Interest: The authors declare no conflict of interest.

\section{References}

1. Gershon, R.K.; Kondo, K. Cell interactions in the induction of tolerance: The role of thymic lymphocytes. Immunology 1970, 18, 723-737. [PubMed]

2. Mier, J.W.; Gallo, R.C. Purification and some characteristics of human T-cell growth factor from phytohemagglutinin-stimulated lymphocyte-conditioned media. Proc. Natl. Acad. Sci. USA 1980, 77, 6134-6138. [CrossRef] [PubMed]

3. MacLennan, I.C.M. Germinal Centers. Annu. Rev. Immunol. 1994, 12, 117-139. [CrossRef] [PubMed]

4. Liu, Y.J.; Malisan, F.; de Bouteiller, O.; Guret, C.; Lebecque, S.; Banchereau, J.; Mills, F.C.; Max, E.E.; Martinez-Valdez, H. Within germinal centers, isotype switching of immunoglobulin genes occurs after the onset of somatic mutation. Immunity 1996, 4, 241-250. [CrossRef] 
5. Claman, H.N.; Chaperon, E.A.; Triplett, R.F. Thymus-marrow cell combinations. Synergism in antibody production. Proc. Soc. Exp. Biol. Med. Soc. Exp. Biol. Med. N. Y. N. 1966, 122, 1167-1171. [CrossRef] [PubMed]

6. Miller, J.F.; Mitchell, G.F. Cell to cell interaction in the immune response. I. Hemolysin-forming cells in neonatally thymectomized mice reconstituted with thymus or thoracic duct lymphocytes. J. Exp. Med. 1968, 128, 801-820. [CrossRef] [PubMed]

7. Breitfeld, D.; Ohl, L.; Kremmer, E.; Ellwart, J.; Sallusto, F.; Lipp, M.; Förster, R. Follicular B helper T cells express CXC chemokine receptor 5, localize to B cell follicles, and support immunoglobulin production. J. Exp. Med. 2000, 192, 1545-1552. [CrossRef] [PubMed]

8. Schaerli, P.; Willimann, K.; Lang, A.B.; Lipp, M.; Loetscher, P.; Moser, B. CXC chemokine receptor 5 expression defines follicular homing T cells with B cell helper function. J. Exp. Med. 2000, 192, 1553-1562. [CrossRef] [PubMed]

9. Kim, C.H.; Rott, L.S.; Clark-Lewis, I.; Campbell, D.J.; Wu, L.; Butcher, E.C. Subspecialization of CXCR5 ${ }^{+}$ T cells: B helper activity is focused in a germinal center-localized subset of CXCR5 ${ }^{+}$T cells. J. Exp. Med. 2001, 193, 1373-1381. [CrossRef] [PubMed]

10. Ansel, K.M.; McHeyzer-Williams, L.J.; Ngo, V.N.; McHeyzer-Williams, M.G.; Cyster, J.G. In vivo-activated CD4 T cells upregulate CXC chemokine receptor 5 and reprogram their response to lymphoid chemokines. J. Exp. Med. 1999, 190, 1123-1134. [CrossRef] [PubMed]

11. Hutloff, A.; Dittrich, A.M.; Beier, K.C.; Eljaschewitsch, B.; Kraft, R.; Anagnostopoulos, I.; Kroczek, R.A. ICOS is an inducible T-cell co-stimulator structurally and functionally related to CD28. Nature 1999, 397, 263-266. [PubMed]

12. van Kooten, C.; Banchereau, J. CD40-CD40 ligand. J. Leukoc. Biol. 2000, 67, 2-17. [PubMed]

13. Vogelzang, A.; McGuire, H.M.; Yu, D.; Sprent, J.; Mackay, C.R.; King, C. A fundamental role for interleukin-21 in the generation of $\mathrm{T}$ follicular helper cells. Immunity 2008, 29, 127-137. [CrossRef] [PubMed]

14. Nurieva, R.I.; Chung, Y.; Hwang, D.; Yang, X.O.; Kang, H.S.; Ma, L.; Wang, Y.; Watowich, S.S.; Jetten, A.M.; Tian, Q.; et al. Generation of $\mathrm{T}$ follicular helper cells is mediated by interleukin-21 but independent of T helper 1, 2, or 17 cell lineages. Immunity 2008, 29, 138-149. [CrossRef] [PubMed]

15. Linterman, M.A.; Beaton, L.; Yu, D.; Ramiscal, R.R.; Srivastava, M.; Hogan, J.J.; Verma, N.K.; Smyth, M.J.; Rigby, R.J.; Vinuesa, C.G. IL-21 acts directly on B cells to regulate Bcl-6 expression and germinal center responses. J. Exp. Med. 2010, 207, 353-363. [CrossRef] [PubMed]

16. Zotos, D.; Coquet, J.M.; Zhang, Y.; Light, A.; D'Costa, K.; Kallies, A.; Corcoran, L.M.; Godfrey, D.I.; Toellner, K.-M.; Smyth, M.J.; et al. IL-21 regulates germinal center B cell differentiation and proliferation through a B cell-intrinsic mechanism. J. Exp. Med. 2010, 207, 365-378. [CrossRef] [PubMed]

17. Ozaki, K.; Spolski, R.; Feng, C.G.; Qi, C.-F.; Cheng, J.; Sher, A.; Morse, H.C., 3rd; Liu, C.; Schwartzberg, P.L.; Leonard, W.J. A critical role for IL-21 in regulating immunoglobulin production. Science 2002, 298, 1630-1634. [CrossRef] [PubMed]

18. Chtanova, T.; Tangye, S.G.; Newton, R.; Frank, N.; Hodge, M.R.; Rolph, M.S.; Mackay, C.R. T follicular helper cells express a distinctive transcriptional profile, reflecting their role as non-Th1/Th2 effector cells that provide help for B cells. J. Immunol. Baltim. Md 1950 2004, 173, 68-78. [CrossRef] [PubMed]

19. Leonard, W.J. Cytokines and immunodeficiency diseases. Nat. Rev. Immunol. 2001, 1, 200-208. [CrossRef] [PubMed]

20. Cooper, J.D.; Smyth, D.J.; Smiles, A.M.; Plagnol, V.; Walker, N.M.; Allen, J.E.; Downes, K.; Barrett, J.C.; Healy, B.C.; Mychaleckyj, J.C.; et al. Meta-analysis of genome-wide association study data identifies additional type 1 diabetes risk loci. Nat. Genet. 2008, 40, 1399-1401. [CrossRef] [PubMed]

21. Hughes, T.; Kim-Howard, X.; Kelly, J.A.; Kaufman, K.M.; Langefeld, C.D.; Ziegler, J.; Sanchez, E.; Kimberly, R.P.; Edberg, J.C.; Ramsey-Goldman, R.; et al. Fine-mapping and transethnic genotyping establish IL2/IL21 genetic association with lupus and localize this genetic effect to IL21. Arthritis Rheum. 2011, 63, 1689-1697. [CrossRef] [PubMed]

22. Bubier, J.A.; Sproule, T.J.; Foreman, O.; Spolski, R.; Shaffer, D.J.; Morse, H.C.; Leonard, W.J.; Roopenian, D.C. A critical role for IL-21 receptor signaling in the pathogenesis of systemic lupus erythematosus in BXSB-Yaa mice. Proc. Natl. Acad. Sci. USA 2009, 106, 1518-1523. [CrossRef] [PubMed]

23. Reinhardt, R.L.; Liang, H.-E.; Locksley, R.M. Cytokine-secreting follicular T cells shape the antibody repertoire. Nat. Immunol. 2009, 10, 385-393. [CrossRef] [PubMed]

24. Crotty, S. Follicular helper CD4 T cells (TFH). Annu. Rev. Immunol. 2011, 29, 621-663. [CrossRef] [PubMed] 
25. Arellano, G.; Ottum, P.A.; Reyes, L.I.; Burgos, P.I.; Naves, R. Stage-Specific Role of Interferon-Gamma in Experimental Autoimmune Encephalomyelitis and Multiple Sclerosis. Front. Immunol. 2015, 6, 492. [CrossRef] [PubMed]

26. Go, N.F.; Castle, B.E.; Barrett, R.; Kastelein, R.; Dang, W.; Mosmann, T.R.; Moore, K.W.; Howard, M. Interleukin 10, a novel $\mathrm{B}$ cell stimulatory factor: Unresponsiveness of $\mathrm{X}$ chromosome-linked immunodeficiency B cells. J. Exp. Med. 1990, 172, 1625-1631. [CrossRef] [PubMed]

27. Wakkach, A.; Cottrez, F.; Groux, H. Can interleukin-10 be used as a true immunoregulatory cytokine? Eur. Cytokine Netw. 2000, 11, 153-160. [PubMed]

28. Banchereau, J.; Rousset, F. Human B lymphocytes: Phenotype, proliferation, and differentiation. Adv. Immunol. 1992, 52, 125-262. [PubMed]

29. Rousset, F.; Garcia, E.; Defrance, T.; Péronne, C.; Vezzio, N.; Hsu, D.H.; Kastelein, R.; Moore, K.W.; Banchereau, J. Interleukin 10 is a potent growth and differentiation factor for activated human B lymphocytes. Proc. Natl. Acad. Sci. USA 1992, 89, 1890-1893. [CrossRef] [PubMed]

30. Lalani, I.; Bhol, K.; Ahmed, A.R. Interleukin-10: Biology, role in inflammation and autoimmunity. Ann. Allergy Asthma Immunol. Off. Publ. Am. Coll. Allergy Asthma Immunol. 1997, 79, 469-483. [CrossRef]

31. Linterman, M.A.; Pierson, W.; Lee, S.K.; Kallies, A.; Kawamoto, S.; Rayner, T.F.; Srivastava, M.; Divekar, D.P.; Beaton, L.; Hogan, J.J.; et al. Foxp3+ follicular regulatory $\mathrm{T}$ cells control the germinal center response. Nat. Med. 2011, 17, 975-982. [CrossRef] [PubMed]

32. Eto, D.; Lao, C.; DiToro, D.; Barnett, B.; Escobar, T.C.; Kageyama, R.; Yusuf, I.; Crotty, S. IL-21 and IL-6 Are Critical for Different Aspects of B Cell Immunity and Redundantly Induce Optimal Follicular Helper CD4 T Cell (Tfh) Differentiation. PLoS ONE 2011, 6, 3. [CrossRef] [PubMed]

33. Karnowski, A.; Chevrier, S.; Belz, G.T.; Mount, A.; Emslie, D.; D’Costa, K.; Tarlinton, D.M.; Kallies, A.; Corcoran, L.M. B and T cells collaborate in antiviral responses via IL-6, IL-21, and transcriptional activator and coactivator, Oct2 and OBF-1. J. Exp. Med. 2012, 209, 2049-2064. [CrossRef] [PubMed]

34. Hirano, T. Interleukin 6 and its Receptor: Ten Years Later. Int. Rev. Immunol. 1998, 16, 249-284. [CrossRef] [PubMed]

35. Meka, R.R.; Venkatesha, S.H.; Dudics, S.; Acharya, B.; Moudgil, K.D. IL-27-induced modulation of autoimmunity and its therapeutic potential. Autoimmun. Rev. 2015, 14, 1131-1141. [CrossRef] [PubMed]

36. Batten, M.; Ramamoorthi, N.; Kljavin, N.M.; Ma, C.S.; Cox, J.H.; Dengler, H.S.; Danilenko, D.M.; Caplazi, P.; Wong, M.; Fulcher, D.A.; et al. IL-27 supports germinal center function by enhancing IL-21 production and the function of T follicular helper cells. J. Exp. Med. 2010, 207, 2895-2906. [CrossRef] [PubMed]

37. Batten, M.; Li, J.; Yi, S.; Kljavin, N.M.; Danilenko, D.M.; Lucas, S.; Lee, J.; de Sauvage, F.J.; Ghilardi, N. Interleukin 27 limits autoimmune encephalomyelitis by suppressing the development of interleukin 17-producing T cells. Nat. Immunol. 2006, 7, 929-936. [CrossRef] [PubMed]

38. Boyman, O.; Kovar, M.; Rubinstein, M.P.; Surh, C.D.; Sprent, J. Selective stimulation of T cell subsets with antibody-cytokine immune complexes. Science 2006, 311, 1924-1927. [CrossRef] [PubMed]

39. Webster, K.E.; Walters, S.; Kohler, R.E.; Mrkvan, T.; Boyman, O.; Surh, C.D.; Grey, S.T.; Sprent, J. In vivo expansion of T reg cells with IL-2-mAb complexes: Induction of resistance to EAE and long-term acceptance of islet allografts without immunosuppression. J. Exp. Med. 2009, 206, 751-760. [CrossRef] [PubMed]

40. Setoguchi, R.; Hori, S.; Takahashi, T.; Sakaguchi, S. Homeostatic maintenance of natural Foxp3(+) CD25(+) CD4(+) regulatory T cells by interleukin (IL)-2 and induction of autoimmune disease by IL-2 neutralization. J. Exp. Med. 2005, 201, 723-735. [CrossRef] [PubMed]

41. Sharma, R.; Fu, S.M.; Ju, S.-T. IL-2: A two-faced master regulator of autoimmunity. J. Autoimmun. 2011, 36, 91-97. [CrossRef] [PubMed]

42. Oestreich, K.J.; Mohn, S.E.; Weinmann, A.S. Molecular mechanisms that control the expression and activity of Bcl-6 in TH1 cells to regulate flexibility with a TFH-like gene profile. Nat. Immunol. 2012, 13, 405-411. [CrossRef] [PubMed]

43. Hsu, H.-C.; Yang, P.; Wang, J.; Wu, Q.; Myers, R.; Chen, J.; Yi, J.; Guentert, T.; Tousson, A.; Stanus, A.L.; et al. Interleukin 17-producing $\mathrm{T}$ helper cells and interleukin 17 orchestrate autoreactive germinal center development in autoimmune BXD2 mice. Nat. Immunol. 2008, 9, 166-175. [CrossRef] [PubMed]

44. Graeber, K.E.; Olsen, N.J. Th17 cell cytokine secretion profile in host defense and autoimmunity. Inflamm. Res. Off. J. Eur. Histamine Res. Soc. Al 2012, 61, 87-96. [CrossRef] [PubMed] 
45. Ding, Y.; Li, J.; Wu, Q.; Yang, P.; Luo, B.; Xie, S.; Druey, K.M.; Zajac, A.J.; Hsu, H.-C.; Mountz, J.D. IL-17RA is essential for optimal localization of follicular Th cells in the germinal center light zone to promote autoantibody-producing B cells. J. Immunol. Baltim. Md 1950 2013, 191, 1614-1624. [CrossRef] [PubMed]

46. Niu, X.; He, D.; Zhang, X.; Yue, T.; Li, N.; Zhang, J.Z.; Dong, C.; Chen, G. IL-21 regulates Th17 cells in rheumatoid arthritis. Hum. Immunol. 2010, 71, 334-341. [CrossRef] [PubMed]

47. Schuurman, H.J.; Bell, E.B.; Gärtner, K.; Hedrich, H.J.; Hansen, A.K.; Kruijt, B.C.; de Vrey, P.; Leyten, R.; Maeder, S.J.; Moutier, R. Comparative evaluation of the immune status of congenitally athymic and euthymic rat strains bred and maintained at different institutes: 2. Athymic rats. J. Exp. Anim. Sci. 1992, 35, 33-48. [PubMed]

48. Dianda, L.; Gulbranson-Judge, A.; Pao, W.; Hayday, A.C.; MacLennan, I.C.; Owen, M.J. Germinal center formation in mice lacking alpha beta T cells. Eur. J. Immunol. 1996, 26, 1603-1607. [CrossRef] [PubMed]

49. Förster, R.; Schubel, A.; Breitfeld, D.; Kremmer, E.; Renner-Müller, I.; Wolf, E.; Lipp, M. CCR7 coordinates the primary immune response by establishing functional microenvironments in secondary lymphoid organs. Cell 1999, 99, 23-33. [CrossRef]

50. Hardtke, S.; Ohl, L.; Förster, R. Balanced expression of CXCR5 and CCR7 on follicular T helper cells determines their transient positioning to lymph node follicles and is essential for efficient B-cell help. Blood 2005, 106, 1924-1931. [CrossRef] [PubMed]

51. Haynes, N.M.; Allen, C.D.C.; Lesley, R.; Ansel, K.M.; Killeen, N.; Cyster, J.G. Role of CXCR5 and CCR7 in follicular Th cell positioning and appearance of a programmed cell death gene- $1^{\text {high }}$ germinal center-associated subpopulation. J. Immunol. Baltim. Md 1950 2007, 179, 5099-5108. [CrossRef] [PubMed]

52. Förster, R.; Mattis, A.E.; Kremmer, E.; Wolf, E.; Brem, G.; Lipp, M. A putative chemokine receptor, BLR1, directs $\mathrm{B}$ cell migration to defined lymphoid organs and specific anatomic compartments of the spleen. Cell 1996, 87, 1037-1047. [CrossRef]

53. Allen, C.D.C.; Ansel, K.M.; Low, C.; Lesley, R.; Tamamura, H.; Fujii, N.; Cyster, J.G. Germinal center dark and light zone organization is mediated by CXCR4 and CXCR5. Nat. Immunol. 2004, 5, 943-952. [CrossRef] [PubMed]

54. Foy, T.M.; Laman, J.D.; Ledbetter, J.A.; Aruffo, A.; Claassen, E.; Noelle, R.J. gp39-CD40 interactions are essential for germinal center formation and the development of B cell memory. J. Exp. Med. 1994, 180, 157-163. [CrossRef] [PubMed]

55. Renshaw, B.R.; Fanslow, W.C.; Armitage, R.J.; Campbell, K.A.; Liggitt, D.; Wright, B.; Davison, B.L.; Maliszewski, C.R. Humoral immune responses in CD40 ligand-deficient mice. J. Exp. Med. 1994, 180, 1889-1900. [CrossRef] [PubMed]

56. Han, S.; Hathcock, K.; Zheng, B.; Kepler, T.B.; Hodes, R.; Kelsoe, G. Cellular interaction in germinal centers. Roles of CD40 ligand and B7-2 in established germinal centers. J. Immunol. Baltim. Md 1950 1995, 155, 556-567. [PubMed]

57. van Essen, D.; Kikutani, H.; Gray, D. CD40 ligand-transduced co-stimulation of T cells in the development of helper function. Nature 1995, 378, 620-623. [CrossRef] [PubMed]

58. Kim, C.H.; Lim, H.W.; Kim, J.R.; Rott, L.; Hillsamer, P.; Butcher, E.C. Unique gene expression program of human germinal center T helper cells. Blood 2004, 104, 1952-1960. [CrossRef] [PubMed]

59. Tafuri, A.; Shahinian, A.; Bladt, F.; Yoshinaga, S.K.; Jordana, M.; Wakeham, A.; Boucher, L.M.; Bouchard, D.; Chan, V.S.; Duncan, G.; et al. ICOS is essential for effective T-helper-cell responses. Nature 2001, 409, 105-109. [CrossRef] [PubMed]

60. Ettinger, R.; Sims, G.P.; Fairhurst, A.-M.; Robbins, R.; da Silva, Y.S.; Spolski, R.; Leonard, W.J.; Lipsky, P.E. IL-21 induces differentiation of human naive and memory B cells into antibody-secreting plasma cells. J. Immunol. Baltim. Md 1950 2005, 175, 7867-7879. [CrossRef] [PubMed]

61. Bryant, V.L.; Ma, C.S.; Avery, D.T.; Li, Y.; Good, K.L.; Corcoran, L.M.; de Waal Malefyt, R.; Tangye, S.G. Cytokine-mediated regulation of human B cell differentiation into Ig-secreting cells: Predominant role of IL-21 produced by CXCR5 ${ }^{+}$T follicular helper cells. J. Immunol. Baltim. Md 1950 2007, 179, 8180-8190. [CrossRef] [PubMed]

62. Vinuesa, C.G.; Cook, M.C.; Angelucci, C.; Athanasopoulos, V.; Rui, L.; Hill, K.M.; Yu, D.; Domaschenz, H.; Whittle, B.; Lambe, T.; et al. A RING-type ubiquitin ligase family member required to repress follicular helper T cells and autoimmunity. Nature 2005, 435, 452-458. [CrossRef] [PubMed] 
63. Rasheed, A.-U.; Rahn, H.-P.; Sallusto, F.; Lipp, M.; Müller, G. Follicular B helper T cell activity is confined to CXCR5(hi)ICOS(hi) CD4 T cells and is independent of CD57 expression. Eur. J. Immunol. 2006, 36, 1892-1903. [CrossRef] [PubMed]

64. Morita, R.; Schmitt, N.; Bentebibel, S.-E.; Ranganathan, R.; Bourdery, L.; Zurawski, G.; Foucat, E.; Dullaers, M.; Oh, S.; Sabzghabaei, N.; et al. Human blood CXCR5 ${ }^{+} \mathrm{CD} 4^{+} \mathrm{T}$ cells are counterparts of $\mathrm{T}$ follicular cells and contain specific subsets that differentially support antibody secretion. Immunity 2011, 34, 108-121. [CrossRef] [PubMed]

65. Sage, P.T.; Francisco, L.M.; Carman, C.V.; Sharpe, A.H. The receptor PD-1 controls follicular regulatory T cells in the lymph nodes and blood. Nat. Immunol. 2013, 14, 152-161. [CrossRef] [PubMed]

66. MacLeod, M.K.L.; David, A.; McKee, A.S.; Crawford, F.; Kappler, J.W.; Marrack, P. Memory CD4 T cells that express CXCR5 provide accelerated help to B cells. J. Immunol. Baltim. Md 1950 2011, 186, 2889-2896. [CrossRef] [PubMed]

67. Weber, J.P.; Fuhrmann, F.; Hutloff, A. T-follicular helper cells survive as long-term memory cells. Eur. J. Immunol. 2012, 42, 1981-1988. [CrossRef] [PubMed]

68. Hale, J.S.; Youngblood, B.; Latner, D.R.; Mohammed, A.U.R.; Ye, L.; Akondy, R.S.; Wu, T.; Iyer, S.S.; Ahmed, R. Distinct memory $\mathrm{CD}^{+} \mathrm{T}$ cells with commitment to $\mathrm{T}$ follicular helper- and $\mathrm{T}$ helper 1-cell lineages are generated after acute viral infection. Immunity 2013, 38, 805-817. [CrossRef] [PubMed]

69. Nurieva, R.I.; Chung, Y.; Martinez, G.J.; Yang, X.O.; Tanaka, S.; Matskevitch, T.D.; Wang, Y.-H.; Dong, C. Bcl6 mediates the development of T follicular helper cells. Science 2009, 325, 1001-1005. [CrossRef] [PubMed]

70. Yu, D.; Rao, S.; Tsai, L.M.; Lee, S.K.; He, Y.; Sutcliffe, E.L.; Srivastava, M.; Linterman, M.; Zheng, L.; Simpson, N.; et al. The transcriptional repressor Bcl-6 directs T follicular helper cell lineage commitment. Immunity 2009, 31, 457-468. [CrossRef] [PubMed]

71. Fazilleau, N.; McHeyzer-Williams, L.J.; Rosen, H.; McHeyzer-Williams, M.G. The function of follicular helper $\mathrm{T}$ cells is regulated by the strength of $\mathrm{T}$ cell antigen receptor binding. Nat. Immunol. 2009, 10, 375-384. [CrossRef] [PubMed]

72. Junt, T.; Fink, K.; Förster, R.; Senn, B.; Lipp, M.; Muramatsu, M.; Zinkernagel, R.M.; Ludewig, B.; Hengartner, H. CXCR5-dependent seeding of follicular niches by B and Th cells augments antiviral B cell responses. J. Immunol. Baltim. Md 1950 2005, 175, 7109-7116. [CrossRef] [PubMed]

73. Poholek, A.C.; Hansen, K.; Hernandez, S.G.; Eto, D.; Chandele, A.; Weinstein, J.S.; Dong, X.; Odegard, J.M.; Kaech, S.M.; Dent, A.L.; et al. In vivo regulation of Bcl6 and T follicular helper cell development. J. Immunol. Baltim. Md 1950 2010, 185, 313-326. [CrossRef] [PubMed]

74. Choi, Y.S.; Kageyama, R.; Eto, D.; Escobar, T.C.; Johnston, R.J.; Monticelli, L.; Lao, C.; Crotty, S. ICOS receptor instructs $\mathrm{T}$ follicular helper cell versus effector cell differentiation via induction of the transcriptional repressor Bcl6. Immunity 2011, 34, 932-946. [CrossRef] [PubMed]

75. Kerfoot, S.M.; Yaari, G.; Patel, J.R.; Johnson, K.L.; Gonzalez, D.G.; Kleinstein, S.H.; Haberman, A.M. Germinal center B cell and T follicular helper cell development initiates in the interfollicular zone. Immunity 2011, 34, 947-960. [CrossRef] [PubMed]

76. Kitano, M.; Moriyama, S.; Ando, Y.; Hikida, M.; Mori, Y.; Kurosaki, T.; Okada, T. Bcl6 protein expression shapes pre-germinal center B cell dynamics and follicular helper T cell heterogeneity. Immunity 2011, 34, 961-972. [CrossRef] [PubMed]

77. Celli, S.; Lemaître, F.; Bousso, P. Real-time manipulation of T cell-dendritic cell interactions in vivo reveals the importance of prolonged contacts for $\mathrm{CD}^{+} \mathrm{T}$ cell activation. Immunity 2007, 27, 625-634. [CrossRef] [PubMed]

78. King, C.; Tangye, S.G.; Mackay, C.R. T follicular helper (TFH) cells in normal and dysregulated immune responses. Annu. Rev. Immunol. 2008, 26, 741-766. [CrossRef] [PubMed]

79. Deenick, E.K.; Chan, A.; Ma, C.S.; Gatto, D.; Schwartzberg, P.L.; Brink, R.; Tangye, S.G. Follicular helper T cell differentiation requires continuous antigen presentation that is independent of unique $\mathrm{B}$ cell signaling. Immunity 2010, 33, 241-253. [CrossRef] [PubMed]

80. Ron, Y.; Sprent, J. T cell priming in vivo: A major role for B cells in presenting antigen to T cells in lymph nodes. J. Immunol. Baltim. Md 1950 1987, 138, 2848-2856. [PubMed]

81. Baumjohann, D.; Okada, T.; Ansel, K.M. Cutting Edge: Distinct waves of BCL6 expression during T follicular helper cell development. J. Immunol. Baltim. Md 1950 2011, 187, 2089-2092. [CrossRef] [PubMed] 
82. Cannons, J.L.; Qi, H.; Lu, K.T.; Dutta, M.; Gomez-Rodriguez, J.; Cheng, J.; Wakeland, E.K.; Germain, R.N.; Schwartzberg, P.L. Optimal germinal center responses require a multistage T cell:B cell adhesion process involving integrins, SLAM-associated protein, and CD84. Immunity 2010, 32, 253-265. [CrossRef] [PubMed]

83. Qi, H.; Cannons, J.L.; Klauschen, F.; Schwartzberg, P.L.; Germain, R.N. SAP-controlled T-B cell interactions underlie germinal centre formation. Nature 2008, 455, 764-769. [CrossRef] [PubMed]

84. Xu, H.; Li, X.; Liu, D.; Li, J.; Zhang, X.; Chen, X.; Hou, S.; Peng, L.; Xu, C.; Liu, W.; et al. Follicular T-helper cell recruitment governed by bystander B cells and ICOS-driven motility. Nature 2013, 496, 523-527. [CrossRef] [PubMed]

85. Johnston, R.J.; Poholek, A.C.; DiToro, D.; Yusuf, I.; Eto, D.; Barnett, B.; Dent, A.L.; Craft, J.; Crotty, S. Bcl6 and Blimp-1 are reciprocal and antagonistic regulators of $\mathrm{T}$ follicular helper cell differentiation. Science 2009, 325, 1006-1010. [CrossRef] [PubMed]

86. Choi, Y.S.; Eto, D.; Yang, J.A.; Lao, C.; Crotty, S. Cutting edge: STAT1 is required for IL-6-mediated Bcl6 induction for early follicular helper cell differentiation. J. Immunol. Baltim. Md 1950 2013, 190, 3049-3053. [CrossRef] [PubMed]

87. Kroenke, M.A.; Eto, D.; Locci, M.; Cho, M.; Davidson, T.; Haddad, E.K.; Crotty, S. Bcl6 and Maf cooperate to instruct human follicular helper CD4 T cell differentiation. J. Immunol. Baltim. Md 1950 2012, 188, 3734-3744. [CrossRef] [PubMed]

88. Klein, U.; Dalla-Favera, R. Germinal centres: Role in B-cell physiology and malignancy. Nat. Rev. Immunol. 2008, 8, 22-33. [CrossRef] [PubMed]

89. Martins, G.; Calame, K. Regulation and functions of Blimp-1 in T and B lymphocytes. Annu. Rev. Immunol. 2008, 26, 133-169. [CrossRef] [PubMed]

90. Bauquet, A.T.; Jin, H.; Paterson, A.M.; Mitsdoerffer, M.; Ho, I.-C.; Sharpe, A.H.; Kuchroo, V.K. The costimulatory molecule ICOS regulates the expression of c-Maf and IL-21 in the development of follicular T helper cells and TH-17 cells. Nat. Immunol. 2009, 10, 167-175. [CrossRef] [PubMed]

91. Hiramatsu, Y.; Suto, A.; Kashiwakuma, D.; Kanari, H.; Kagami, S.; Ikeda, K.; Hirose, K.; Watanabe, N.; Grusby, M.J.; Iwamoto, I.; et al. c-Maf activates the promoter and enhancer of the IL-21 gene, and TGF-beta inhibits c-Maf-induced IL-21 production in CD4 ${ }^{+}$T cells. J. Leukoc. Biol. 2010, 87, 703-712. [CrossRef] [PubMed]

92. Kwon, H.; Thierry-Mieg, D.; Thierry-Mieg, J.; Kim, H.-P.; Oh, J.; Tunyaplin, C.; Carotta, S.; Donovan, C.E.; Goldman, M.L.; Tailor, P.; et al. Analysis of interleukin-21-induced Prdm1 gene regulation reveals functional cooperation of STAT3 and IRF4 transcription factors. Immunity 2009, 31, 941-952. [CrossRef] [PubMed]

93. Bollig, N.; Brüstle, A.; Kellner, K.; Ackermann, W.; Abass, E.; Raifer, H.; Camara, B.; Brendel, C.; Giel, G.; Bothur, E.; et al. Transcription factor IRF4 determines germinal center formation through follicular T-helper cell differentiation. Proc. Natl. Acad. Sci. USA 2012, 109, 8664-8669. [CrossRef] [PubMed]

94. Lohoff, M.; Mittrücker, H.-W.; Prechtl, S.; Bischof, S.; Sommer, F.; Kock, S.; Ferrick, D.A.; Duncan, G.S.; Gessner, A.; Mak, T.W. Dysregulated T helper cell differentiation in the absence of interferon regulatory factor 4. Proc. Natl. Acad. Sci. USA 2002, 99, 11808-11812. [CrossRef] [PubMed]

95. Brüstle, A.; Heink, S.; Huber, M.; Rosenplänter, C.; Stadelmann, C.; Yu, P.; Arpaia, E.; Mak, T.W.; Kamradt, T.; Lohoff, M. The development of inflammatory $\mathrm{T}(\mathrm{H})-17$ cells requires interferon-regulatory factor 4. Nat. Immunol. 2007, 8, 958-966. [CrossRef] [PubMed]

96. Staudt, V.; Bothur, E.; Klein, M.; Lingnau, K.; Reuter, S.; Grebe, N.; Gerlitzki, B.; Hoffmann, M.; Ulges, A.; Taube, C.; et al. Interferon-regulatory factor 4 is essential for the developmental program of T helper 9 cells. Immunity 2010, 33, 192-202. [CrossRef] [PubMed]

97. Serre, K.; Mohr, E.; Bénézech, C.; Bird, R.; Khan, M.; Caamaño, J.H.; Cunningham, A.F.; Maclennan, I.C.M. Selective effects of NF-kB1 deficiency in $\mathrm{CD}^{+} \mathrm{T}$ cells on Th2 and TFh induction by alum-precipitated protein vaccines. Eur. J. Immunol. 2011, 41, 1573-1582. [CrossRef] [PubMed]

98. Auderset, F.; Schuster, S.; Fasnacht, N.; Coutaz, M.; Charmoy, M.; Koch, U.; Favre, S.; Wilson, A.; Trottein, F.; Alexander, J.; et al. Notch signaling regulates follicular helper T cell differentiation. J. Immunol. Baltim. Md 1950 2013, 191, 2344-2350. [CrossRef] [PubMed]

99. Liu, X.; Chen, X.; Zhong, B.; Wang, A.; Wang, X.; Chu, F.; Nurieva, R.I.; Yan, X.; Chen, P.; van der Flier, L.G.; et al. Transcription factor achaete-scute homologue 2 initiates follicular T-helper-cell development. Nature 2014, 507, 513-518. [CrossRef] [PubMed] 
100. Shevach, E.M. Regulatory T Cells in Autoimmmunity. Annu. Rev. Immunol. 2000, 18, 423-449. [CrossRef] [PubMed]

101. Lim, H.W.; Hillsamer, P.; Banham, A.H.; Kim, C.H. Cutting edge: Direct suppression of B cells by CD4 ${ }^{+}$ CD25 $5^{+}$regulatory T cells. J. Immunol. Baltim. Md 1950 2005, 175, 4180-4183. [CrossRef] [PubMed]

102. Lim, H.W.; Hillsamer, P.; Kim, C.H. Regulatory T cells can migrate to follicles upon T cell activation and suppress GC-Th cells and GC-Th cell-driven B cell responses. J. Clin. Investig. 2004, 114, 1640-1649. [CrossRef] [PubMed]

103. Chung, Y.; Tanaka, S.; Chu, F.; Nurieva, R.I.; Martinez, G.J.; Rawal, S.; Wang, Y.-H.; Lim, H.; Reynolds, J.M.; Zhou, X.; et al. Follicular regulatory T cells expressing Foxp3 and Bcl-6 suppress germinal center reactions. Nat. Med. 2011, 17, 983-988. [CrossRef] [PubMed]

104. Wollenberg, I.; Agua-Doce, A.; Hernández, A.; Almeida, C.; Oliveira, V.G.; Faro, J.; Graca, L. Regulation of the germinal center reaction by Foxp3 ${ }^{+}$follicular regulatory T cells. J. Immunol. Baltim. Md 1950 2011, 187, 4553-4560. [CrossRef] [PubMed]

105. Barrat, F.J.; Cua, D.J.; Boonstra, A.; Richards, D.F.; Crain, C.; Savelkoul, H.F.; de Waal-Malefyt, R.; Coffman, R.L.; Hawrylowicz, C.M.; O'Garra, A. In vitro generation of interleukin 10-producing regulatory CD4(+) $\mathrm{T}$ cells is induced by immunosuppressive drugs and inhibited by T helper type 1 (Th1)- and Th2-inducing cytokines. J. Exp. Med. 2002, 195, 603-616. [CrossRef] [PubMed]

106. Horwitz, D.A.; Zheng, S.G.; Gray, J.D. Natural and TGF- $\beta$-induced Foxp $3^{+} \mathrm{CD} 4^{+} \mathrm{CD} 25^{+}$regulatory T cells are not mirror images of each other. Trends Immunol. 2008, 29, 429-435. [CrossRef] [PubMed]

107. Alexander, C.-M.; Tygrett, L.T.; Boyden, A.W.; Wolniak, K.L.; Legge, K.L.; Waldschmidt, T.J. T regulatory cells participate in the control of germinal centre reactions. Immunology 2011, 133, 452-468. [CrossRef] [PubMed]

108. Josefowicz, S.Z.; Niec, R.E.; Kim, H.Y.; Treuting, P.; Chinen, T.; Zheng, Y.; Umetsu, D.T.; Rudensky, A.Y. Extrathymically generated regulatory T cells control mucosal TH2 inflammation. Nature 2012, 482, 395-399. [CrossRef] [PubMed]

109. Sage, P.T.; Sharpe, A.H. T follicular regulatory cells in the regulation of B cell responses. Trends Immunol. 2015, 36, 410-418. [CrossRef] [PubMed]

110. Ballesteros-Tato, A.; León, B.; Graf, B.A.; Moquin, A.; Adams, P.S.; Lund, F.E.; Randall, T.D. Interleukin-2 inhibits germinal center formation by limiting $\mathrm{T}$ follicular helper cell differentiation. Immunity 2012, 36, 847-856. [CrossRef] [PubMed]

111. Peuchmaur, M.; Emilie, D.; Crevon, M.C.; Brousse, N.; Gaulard, P.; D'Agay, M.F.; Galanaud, P.; Solal-Celigny, P. Interleukin-2 and interferon-gamma production in follicular lymphomas. Am. J. Clin. Pathol. 1991, 95, 55-62. [PubMed]

112. Vyth-Dreese, F.A.; Boot, H.; Dellemijn, T.A.; Majoor, D.M.; Oomen, L.C.; Laman, J.D.; Van Meurs, M.; De Weger, R.A.; De Jong, D. Localization in situ of costimulatory molecules and cytokines in B-cell non-Hodgkin's lymphoma. Immunology 1998, 94, 580-586. [CrossRef] [PubMed]

113. Emilie, D.; Peuchmaur, M.; Maillot, M.C.; Crevon, M.C.; Brousse, N.; Delfraissy, J.F.; Dormont, J.; Galanaud, P. Production of interleukins in human immunodeficiency virus-1-replicating lymph nodes. J. Clin. Investig. 1990, 86, 148-159. [CrossRef] [PubMed]

114. Heinen, E. In Vivo Immunology: Regulatory Processes During Lymphopoiesis and Immunopoiesis, Proceedings of the International Conference on Lymphatic Tissues and Germinal Centers in Immune Reactions 1993: Liege, B.; In Series Advances in Experimental Medicine and Biology; Springer: New York, NY, USA, 1994; Volume 355.

115. Bogen, S.A.; Fogelman, I.; Abbas, A.K. Analysis of IL-2, IL-4, and IFN-gamma-producing cells in situ during immune responses to protein antigens. J. Immunol. Baltim. Md 1950 1993, 150, 4197-4205. [PubMed]

116. Butch, A.W.; Chung, G.H.; Hoffmann, J.W.; Nahm, M.H. Cytokine expression by germinal center cells. J. Immunol. Baltim. Md 1950 1993, 150, 39-47. [PubMed]

117. Toellner, K.M.; Scheel-Toellner, D.; Sprenger, R.; Duchrow, M.; Trümper, L.H.; Ernst, M.; Flad, H.D.; Gerdes, J. The human germinal centre cells, follicular dendritic cells and germinal centre T cells produce B cell-stimulating cytokines. Cytokine 1995, 7, 344-354. [CrossRef] [PubMed]

118. King, I.L.; Mohrs, M. IL-4-producing CD4 ${ }^{+} \mathrm{T}$ cells in reactive lymph nodes during helminth infection are T follicular helper cells. J. Exp. Med. 2009, 206, 1001-1007. [CrossRef] [PubMed] 
119. Zaretsky, A.G.; Taylor, J.J.; King, I.L.; Marshall, F.A.; Mohrs, M.; Pearce, E.J. T follicular helper cells differentiate from Th2 cells in response to helminth antigens. J. Exp. Med. 2009, 206, 991-999. [CrossRef] [PubMed]

120. Fazilleau, N.; Eisenbraun, M.D.; Malherbe, L.; Ebright, J.N.; Pogue-Caley, R.R.; McHeyzer-Williams, L.J.; McHeyzer-Williams, M.G. Lymphoid reservoirs of antigen-specific memory T helper cells. Nat. Immunol. 2007, 8, 753-761. [CrossRef] [PubMed]

121. Lüthje, K.; Kallies, A.; Shimohakamada, Y.; Belz, G.T.; Light, A.; Tarlinton, D.M.; Nutt, S.L. The development and fate of follicular helper T cells defined by an IL-21 reporter mouse. Nat. Immunol. 2012, 13, 491-498. [CrossRef] [PubMed]

122. Tsuji, M.; Komatsu, N.; Kawamoto, S.; Suzuki, K.; Kanagawa, O.; Honjo, T.; Hori, S.; Fagarasan, S. Preferential generation of follicular B helper T cells from Foxp3 ${ }^{+} \mathrm{T}$ cells in gut Peyer's patches. Science 2009, 323, 1488-1492. [CrossRef] [PubMed]

123. Kopf, M.; Herren, S.; Wiles, M.V.; Pepys, M.B.; Kosco-Vilbois, M.H. Interleukin 6 influences germinal center development and antibody production via a contribution of C3 complement component. J. Exp. Med. 1998, 188, 1895-1906. [CrossRef] [PubMed]

124. McGuire, H.M.; Vogelzang, A.; Warren, J.; Loetsch, C.; Natividad, K.D.; Chan, T.D.; Brink, R.; Batten, M.; King, C. IL-21 and IL-4 Collaborate To Shape T-Dependent Antibody Responses. J. Immunol. 2015, 195, 5123-5135. [CrossRef] [PubMed]

125. Chavele, K.-M.; Merry, E.; Ehrenstein, M.R. Cutting edge: Circulating plasmablasts induce the differentiation of human T follicular helper cells via IL-6 production. J. Immunol. Baltim. Md 1950 2015, 194, 2482-2485. [CrossRef] [PubMed]

126. Wu, Y.; El Shikh, M.E.M.; El Sayed, R.M.; Best, A.M.; Szakal, A.K.; Tew, J.G. IL-6 produced by immune complex-activated follicular dendritic cells promotes germinal center reactions, IgG responses and somatic hypermutation. Int. Immunol. 2009, 21, 745-756. [CrossRef] [PubMed]

127. Ozaki, K.; Kikly, K.; Michalovich, D.; Young, P.R.; Leonard, W.J. Cloning of a type I cytokine receptor most related to the IL-2 receptor beta chain. Proc. Natl. Acad. Sci. USA 2000, 97, 11439-11444. [CrossRef] [PubMed]

128. Kasaian, M.T.; Whitters, M.J.; Carter, L.L.; Lowe, L.D.; Jussif, J.M.; Deng, B.; Johnson, K.A.; Witek, J.S.; Senices, M.; Konz, R.F.; et al. IL-21 limits NK cell responses and promotes antigen-specific T cell activation: A mediator of the transition from innate to adaptive immunity. Immunity 2002, 16, 559-569. [CrossRef]

129. Avery, D.T.; Deenick, E.K.; Ma, C.S.; Suryani, S.; Simpson, N.; Chew, G.Y.; Chan, T.D.; Palendira, U.; Bustamante, J.; Boisson-Dupuis, S.; et al. B cell-intrinsic signaling through IL-21 receptor and STAT3 is required for establishing long-lived antibody responses in humans. J. Exp. Med. 2010, 207, 155-171. [CrossRef] [PubMed]

130. Zeng, R.; Spolski, R.; Casas, E.; Zhu, W.; Levy, D.E.; Leonard, W.J. The molecular basis of IL-21-mediated proliferation. Blood 2007, 109, 4135-4142. [CrossRef] [PubMed]

131. Asao, H.; Okuyama, C.; Kumaki, S.; Ishii, N.; Tsuchiya, S.; Foster, D.; Sugamura, K. Cutting edge: The common gamma-chain is an indispensable subunit of the IL-21 receptor complex. J. Immunol. Baltim. Md 1950 2001, 167, 1-5. [CrossRef] [PubMed]

132. Delgoffe, G.M.; Vignali, D.A.A. STAT heterodimers in immunity: A mixed message or a unique signal? JAK-STAT 2013, 2, e23060. [CrossRef] [PubMed]

133. Heinrich, P.C.; Behrmann, I.; Müller-Newen, G.; Schaper, F.; Graeve, L. Interleukin-6-type cytokine signalling through the gp130/Jak/STAT pathway. Biochem. J. 1998, 334 (Pt 2), 297-314. [CrossRef] [PubMed]

134. Eddahri, F.; Denanglaire, S.; Bureau, F.; Spolski, R.; Leonard, W.J.; Leo, O.; Andris, F. Interleukin-6/STAT3 signaling regulates the ability of naive T cells to acquire B-cell help capacities. Blood 2009, 113, 2426-2433. [CrossRef] [PubMed]

135. Fornek, J.L.; Tygrett, L.T.; Waldschmidt, T.J.; Poli, V.; Rickert, R.C.; Kansas, G.S. Critical role for Stat3 in T-dependent terminal differentiation of IgG B cells. Blood 2006, 107, 1085-1091. [CrossRef] [PubMed]

136. Ozaki, K.; Spolski, R.; Ettinger, R.; Kim, H.-P.; Wang, G.; Qi, C.-F.; Hwu, P.; Shaffer, D.J.; Akilesh, S.; Roopenian, D.C.; et al. Regulation of B cell differentiation and plasma cell generation by IL-21, a novel inducer of Blimp-1 and Bcl-6. J. Immunol. Baltim. Md 1950 2004, 173, 5361-5371. [CrossRef] [PubMed]

137. Lee, S.K.; Rigby, R.J.; Zotos, D.; Tsai, L.M.; Kawamoto, S.; Marshall, J.L.; Ramiscal, R.R.; Chan, T.D.; Gatto, D.; Brink, R.; et al. B cell priming for extrafollicular antibody responses requires Bcl-6 expression by $\mathrm{T}$ cells. J. Exp. Med. 2011, 208, 1377-1388. [CrossRef] [PubMed] 
138. Dienz, O.; Eaton, S.M.; Bond, J.P.; Neveu, W.; Moquin, D.; Noubade, R.; Briso, E.M.; Charland, C.; Leonard, W.J.; Ciliberto, G.; et al. The induction of antibody production by IL-6 is indirectly mediated by IL-21 produced by CD4+ T cells. J. Exp. Med. 2009, 206, 69-78. [CrossRef] [PubMed]

139. Batten, M.; Ghilardi, N. The biology and therapeutic potential of interleukin 27. J. Mol. Med. 2007, 85, 661-672. [CrossRef] [PubMed]

140. Shields, D.C.; Harmon, D.L.; Nunez, F.; Whitehead, A.S. The evolution of haematopoietic cytokine/receptor complexes. Cytokine 1995, 7, 679-688. [CrossRef] [PubMed]

141. Fontenot, J.D.; Rasmussen, J.P.; Gavin, M.A.; Rudensky, A.Y. A function for interleukin 2 in Foxp3-expressing regulatory T cells. Nat. Immunol. 2005, 6, 1142-1151. [CrossRef] [PubMed]

142. Willerford, D.M.; Chen, J.; Ferry, J.A.; Davidson, L.; Ma, A.; Alt, F.W. Interleukin-2 receptor alpha chain regulates the size and content of the peripheral lymphoid compartment. Immunity 1995, 3, 521-530. [CrossRef]

143. Attridge, K.; Wang, C.J.; Wardzinski, L.; Kenefeck, R.; Chamberlain, J.L.; Manzotti, C.; Kopf, M.; Walker, L.S.K. IL-21 inhibits T cell IL-2 production and impairs Treg homeostasis. Blood 2012, 119, 4656-4664. [CrossRef] [PubMed]

144. Schmitz, I.; Schneider, C.; Fröhlich, A.; Frebel, H.; Christ, D.; Leonard, W.J.; Sparwasser, T.; Oxenius, A.; Freigang, S.; Kopf, M. IL-21 restricts virus-driven Treg cell expansion in chronic LCMV infection. PLoS Pathog. 2013, 9, e1003362. [CrossRef] [PubMed]

145. Bennett, C.L.; Ochs, H.D. IPEX is a unique X-linked syndrome characterized by immune dysfunction, polyendocrinopathy, enteropathy, and a variety of autoimmune phenomena. Curr. Opin. Pediatr. 2001, 13, 533-538. [CrossRef] [PubMed]

146. Ramsdell, F.; Ziegler, S.F. FOXP3 and scurfy: How it all began. Nat. Rev. Immunol. 2014, 14, 343-349. [CrossRef] [PubMed]

147. Nurieva, R.; Yang, X.O.; Martinez, G.; Zhang, Y.; Panopoulos, A.D.; Ma, L.; Schluns, K.; Tian, Q.; Watowich, S.S.; Jetten, A.M.; et al. Essential autocrine regulation by IL-21 in the generation of inflammatory T cells. Nature 2007, 448, 480-483. [CrossRef] [PubMed]

148. Korn, T.; Bettelli, E.; Gao, W.; Awasthi, A.; Jäger, A.; Strom, T.B.; Oukka, M.; Kuchroo, V.K. IL-21 initiates an alternative pathway to induce proinflammatory T(H)17 cells. Nature 2007, 448, 484-487. [CrossRef] [PubMed]

149. Vogelzang, A.; McGuire, H.M.; Liu, S.M.; Gloss, B.; Mercado, K.; Earls, P.; Dinger, M.E.; Batten, M.; Sprent, J.; King, C. IL-21 contributes to fatal inflammatory disease in the absence of Foxp $3^{+}$T regulatory cells. J. Immunol. Baltim. Md 1950 2014, 192, 1404-1414. [CrossRef] [PubMed]

150. Clough, L.E.; Wang, C.J.; Schmidt, E.M.; Booth, G.; Hou, T.Z.; Ryan, G.A.; Walker, L.S.K. Release from regulatory $\mathrm{T}$ cell-mediated suppression during the onset of tissue-specific autoimmunity is associated with elevated IL-21. J. Immunol. Baltim. Md 1950 2008, 180, 5393-5401. [CrossRef] [PubMed]

151. Li, Y.; Yee, C. IL-21 mediated Foxp3 suppression leads to enhanced generation of antigen-specific CD8 ${ }^{+}$ cytotoxic T lymphocytes. Blood 2008, 111, 229-235. [CrossRef] [PubMed]

152. Piao, W.-H.; Jee, Y.H.; Liu, R.L.; Coons, S.W.; Kala, M.; Collins, M.; Young, D.A.; Campagnolo, D.I.; Vollmer, T.L.; Bai, X.-F.; et al. IL-21 modulates $\mathrm{CD} 4{ }^{+} \mathrm{CD} 25^{+}$regulatory T-cell homeostasis in experimental autoimmune encephalomyelitis. Scand. J. Immunol. 2008, 67, 37-46. [CrossRef] [PubMed]

153. Johnston, R.J.; Choi, Y.S.; Diamond, J.A.; Yang, J.A.; Crotty, S. STAT5 is a potent negative regulator of TFH cell differentiation. J. Exp. Med. 2012, 209, 243-250. [CrossRef] [PubMed]

154. Nurieva, R.I.; Podd, A.; Chen, Y.; Alekseev, A.M.; Yu, M.; Qi, X.; Huang, H.; Wen, R.; Wang, J.; Li, H.S.; et al. STAT5 protein negatively regulates $\mathrm{T}$ follicular helper (Tfh) cell generation and function. J. Biol. Chem. 2012, 287, 11234-11239. [CrossRef] [PubMed]

155. Ding, Y.; Li, J.; Yang, P.; Luo, B.; Wu, Q.; Zajac, A.J.; Wildner, O.; Hsu, H.-C.; Mountz, J.D. Interleukin-21 Promotes Germinal Center Reaction by Skewing the Follicular Regulatory T Cell to Follicular Helper T Cell Balance in Autoimmune BXD2 Mice. Arthritis Rheumatol. 2014, 66, 2601-2612. [CrossRef] [PubMed]

156. Sahoo, A.; Alekseev, A.; Tanaka, K.; Obertas, L.; Lerman, B.; Haymaker, C.; Clise-Dwyer, K.; McMurray, J.S.; Nurieva, R. Batf is important for IL-4 expression in T follicular helper cells. Nat. Commun. 2015, 6, 7997. [CrossRef] [PubMed] 
157. Betz, B.C.; Jordan-Williams, K.L.; Wang, C.; Kang, S.G.; Liao, J.; Logan, M.R.; Kim, C.H.; Taparowsky, E.J. Batf coordinates multiple aspects of $\mathrm{B}$ and $\mathrm{T}$ cell function required for normal antibody responses. J. Exp. Med. 2010, 207, 933-942. [CrossRef] [PubMed]

158. Ise, W.; Kohyama, M.; Schraml, B.U.; Zhang, T.; Schwer, B.; Basu, U.; Alt, F.W.; Tang, J.; Oltz, E.M.; Murphy, T.L.; et al. Batf controls the global regulators of class switch recombination in both B and T cells. Nat. Immunol. 2011, 12, 536-543. [CrossRef] [PubMed]

159. Pène, J.; Gauchat, J.-F.; Lécart, S.; Drouet, E.; Guglielmi, P.; Boulay, V.; Delwail, A.; Foster, D.; Lecron, J.-C.; Yssel, H. Cutting edge: IL-21 is a switch factor for the production of IgG1 and IgG3 by human B cells. J. Immunol. Baltim. Md 1950 2004, 172, 5154-5157. [CrossRef] [PubMed]

160. Pène, J.; Guglielmi, L.; Gauchat, J.-F.; Harrer, N.; Woisetschläger, M.; Boulay, V.; Fabre, J.-M.; Demoly, P.; Yssel, H. IFN-gamma-mediated inhibition of human IgE synthesis by IL-21 is associated with a polymorphism in the IL-21R gene. J. Immunol. Baltim. Md 1950 2006, 177, 5006-5013. [CrossRef] [PubMed]

161. Kotlarz, D.; Ziętara, N.; Uzel, G.; Weidemann, T.; Braun, C.J.; Diestelhorst, J.; Krawitz, P.M.; Robinson, P.N.; Hecht, J.; Puchałka, J.; et al. Loss-of-function mutations in the IL-21 receptor gene cause a primary immunodeficiency syndrome. J. Exp. Med. 2013, 210, 433-443. [CrossRef] [PubMed]

162. Suto, A.; Nakajima, H.; Hirose, K.; Suzuki, K.; Kagami, S.; Seto, Y.; Hoshimoto, A.; Saito, Y.; Foster, D.C.; Iwamoto, I. Interleukin 21 prevents antigen-induced IgE production by inhibiting germ line C(epsilon) transcription of IL-4-stimulated B cells. Blood 2002, 100, 4565-4573. [CrossRef] [PubMed]

163. Kitayama, D.; Sakamoto, A.; Arima, M.; Hatano, M.; Miyazaki, M.; Tokuhisa, T. A role for Bcl6 in sequential class switch recombination to IgE in B cells stimulated with IL-4 and IL-21. Mol. Immunol. 2008, 45, 1337-1345. [CrossRef] [PubMed]

164. Ma, C.S.; Suryani, S.; Avery, D.T.; Chan, A.; Nanan, R.; Santner-Nanan, B.; Deenick, E.K.; Tangye, S.G. Early commitment of naïve human $\mathrm{CD}^{+} \mathrm{T}$ cells to the $\mathrm{T}$ follicular helper $\left(\mathrm{T}_{\mathrm{FH}}\right)$ cell lineage is induced by IL-12. Immunol. Cell Biol. 2009, 87, 590-600. [CrossRef] [PubMed]

165. Yusuf, I.; Kageyama, R.; Monticelli, L.; Johnston, R.J.; Ditoro, D.; Hansen, K.; Barnett, B.; Crotty, S. Germinal center T follicular helper cell IL-4 production is dependent on signaling lymphocytic activation molecule receptor (CD150). J. Immunol. Baltim. Md 1950 2010, 185, 190-202. [CrossRef] [PubMed]

166. Lee, S.K.; Silva, D.G.; Martin, J.L.; Pratama, A.; Hu, X.; Chang, P.-P.; Walters, G.; Vinuesa, C.G. Interferon- $\gamma$ Excess Leads to Pathogenic Accumulation of Follicular Helper T Cells and Germinal Centers. Immunity 2012, 37, 880-892. [CrossRef] [PubMed]

167. Conti, P.; Kempuraj, D.; Kandere, K.; Di Gioacchino, M.; Barbacane, R.C.; Castellani, M.L.; Felaco, M.; Boucher, W.; Letourneau, R.; Theoharides, T.C. IL-10, an inflammatory/inhibitory cytokine, but not always. Immunol. Lett. 2003, 86, 123-129. [CrossRef]

168. Ebert, L.M.; Horn, M.P.; Lang, A.B.; Moser, B. B cells alter the phenotype and function of follicular-homing CXCR5 $^{+}$T cells. Eur. J. Immunol. 2004, 34, 3562-3571. [CrossRef] [PubMed]

169. Löhning, M.; Hutloff, A.; Kallinich, T.; Mages, H.W.; Bonhagen, K.; Radbruch, A.; Hamelmann, E.; Kroczek, R.A. Expression of ICOS in vivo defines CD4 ${ }^{+}$effector T cells with high inflammatory potential and a strong bias for secretion of interleukin 10. J. Exp. Med. 2003, 197, 181-193. [CrossRef] [PubMed]

170. Arpin, C.; Déchanet, J.; Van Kooten, C.; Merville, P.; Grouard, G.; Brière, F.; Banchereau, J.; Liu, Y.J. Generation of memory B cells and plasma cells in vitro. Science 1995, 268, 720-722. [CrossRef] [PubMed]

171. Balasa, B.; Van Gunst, K.; Jung, N.; Balakrishna, D.; Santamaria, P.; Hanafusa, T.; Itoh, N.; Sarvetnick, N. Islet-specific expression of IL-10 promotes diabetes in nonobese diabetic mice independent of Fas, perforin, TNF receptor-1, and TNF receptor-2 molecules. J. Immunol. Baltim. Md 1950 2000, 165, 2841-2849. [CrossRef] [PubMed]

172. Cai, G.; Nie, X.; Zhang, W.; Wu, B.; Lin, J.; Wang, H.; Jiang, C.; Shen, Q. A Regulatory Role for IL-10 Receptor Signaling in Development and B Cell Help of T Follicular Helper Cells in Mice. J. Immunol. 2012, 189, 1294-1302. [CrossRef] [PubMed]

173. Wu, H.Y.; Quintana, F.J.; Weiner, H.L. Nasal anti-CD3 antibody ameliorates lupus by inducing an IL-10-secreting $\mathrm{CD}^{+} \mathrm{CD} 25^{-} \mathrm{LAP}^{+}$regulatory $\mathrm{T}$ cell and is associated with down-regulation of IL-17 ${ }^{+} \mathrm{CD}^{+} \mathrm{ICOS}^{+} \mathrm{CXCR}^{+}$follicular helper T cells. J. Immunol. Baltim. Md 1950 2008, 181, 6038-6050. [CrossRef] [PubMed]

174. Tangye, S.G.; Ma, C.S.; Brink, R.; Deenick, E.K. The good, the bad and the ugly- $\mathrm{T}_{\mathrm{FH}}$ cells in human health and disease. Nat. Rev. Immunol. 2013, 13, 412-426. [CrossRef] [PubMed] 
175. Moudgil, K.D.; Choubey, D. Cytokines in autoimmunity: Role in induction, regulation, and treatment. J. Interferon Cytokine Res. Off. J. Int. Soc. Interferon Cytokine Res. 2011, 31, 695-703. [CrossRef] [PubMed]

176. Sweet, R.A.; Lee, S.K.; Vinuesa, C.G. Developing connections amongst key cytokines and dysregulated germinal centers in autoimmunity. Curr. Opin. Immunol. 2012, 24, 658-664. [CrossRef] [PubMed]

177. Shi, G.-X.; Harrison, K.; Wilson, G.L.; Moratz, C.; Kehrl, J.H. RGS13 regulates germinal center B lymphocytes responsiveness to CXC chemokine ligand (CXCL)12 and CXCL13. J. Immunol. Baltim. Md 1950 2002, 169, 2507-2515. [CrossRef] [PubMed]

178. Han, J.-I.; Huang, N.-N.; Kim, D.-U.; Kehrl, J.H. RGS1 and RGS13 mRNA silencing in a human B lymphoma line enhances responsiveness to chemoattractants and impairs desensitization. J. Leukoc. Biol. 2006, 79, 1357-1368. [CrossRef] [PubMed]

179. Korn, T.; Bettelli, E.; Oukka, M.; Kuchroo, V.K. IL-17 and Th17 Cells. Annu. Rev. Immunol. 2009, $27,485-517$. [CrossRef] [PubMed]

180. Mitsdoerffer, M.; Lee, Y.; Jäger, A.; Kim, H.-J.; Korn, T.; Kolls, J.K.; Cantor, H.; Bettelli, E.; Kuchroo, V.K. Proinflammatory T helper type 17 cells are effective B-cell helpers. Proc. Natl. Acad. Sci. USA 2010, 107, 14292-14297. [CrossRef] [PubMed]

181. Hirota, K.; Turner, J.-E.; Villa, M.; Duarte, J.H.; Demengeot, J.; Steinmetz, O.M.; Stockinger, B. Plasticity of Th17 cells in Peyer's patches is responsible for the induction of T cell-dependent IgA responses. Nat. Immunol. 2013, 14, 372-379. [CrossRef] [PubMed]

182. Wichner, K.; Stauss, D.; Kampfrath, B.; Krüger, K.; Müller, G.; Rehm, A.; Lipp, M.; Höpken, U.E. Dysregulated development of IL-17-and IL-21-expressing follicular helper T cells and increased germinal center formation in the absence of ROR $\gamma$ t. FASEB J. Off. Publ. Fed. Am. Soc. Exp. Biol. 2015. [CrossRef]

183. Noguchi, M.; Yi, H.; Rosenblatt, H.M.; Filipovich, A.H.; Adelstein, S.; Modi, W.S.; McBride, O.W.; Leonard, W.J. Interleukin-2 receptor gamma chain mutation results in X-linked severe combined immunodeficiency in humans. Cell 1993, 73, 147-157. [CrossRef]

184. Buckley, R.H.; Schiff, R.I.; Schiff, S.E.; Markert, M.L.; Williams, L.W.; Harville, T.O.; Roberts, J.L.; Puck, J.M. Human severe combined immunodeficiency: Genetic, phenotypic, and functional diversity in one hundred eight infants. J. Pediatr. 1997, 130, 378-387. [CrossRef]

185. Elsaesser, H.; Sauer, K.; Brooks, D.G. IL-21 is required to control chronic viral infection. Science 2009, 324, 1569-1572. [CrossRef] [PubMed]

186. Spolski, R.; Leonard, W.J. Interleukin-21: Basic biology and implications for cancer and autoimmunity. Annu. Rev. Immunol. 2008, 26, 57-79. [CrossRef] [PubMed]

187. Yi, J.S.; Du, M.; Zajac, A.J. A vital role for interleukin-21 in the control of a chronic viral infection. Science 2009, 324, 1572-1576. [CrossRef] [PubMed]

188. Kotlarz, D.; Ziętara, N.; Milner, J.D.; Klein, C. Human IL-21 and IL-21R deficiencies: Two novel entities of primary immunodeficiency. Curr. Opin. Pediatr. 2014, 26, 704-712. [CrossRef] [PubMed]

189. Salzer, E.; Kansu, A.; Sic, H.; Májek, P.; Ikincioğullari, A.; Dogu, F.E.; Prengemann, N.K.; Santos-Valente, E.; Pickl, W.F.; Bilic, I.; et al. Early-onset inflammatory bowel disease and common variable immunodeficiency-like disease caused by IL-21 deficiency. J. Allergy Clin. Immunol. 2014, 133, 1651-1659.e12. [CrossRef] [PubMed]

190. Márquez, A.; Orozco, G.; Martínez, A.; Palomino-Morales, R.; Fernández-Arquero, M.; Mendoza, J.L.; Taxonera, C.; Díaz-Rubio, M.; Gómez-García, M.; Nieto, A.; et al. Novel association of the interleukin 2-interleukin 21 region with inflammatory bowel disease. Am. J. Gastroenterol. 2009, 104, 1968-1975. [CrossRef] [PubMed]

191. van Heel, D.A.; Franke, L.; Hunt, K.A.; Gwilliam, R.; Zhernakova, A.; Inouye, M.; Wapenaar, M.C.; Barnardo, M.C.N.M.; Bethel, G.; Holmes, G.K.T.; et al. A genome-wide association study for celiac disease identifies risk variants in the region harboring IL2 and IL21. Nat. Genet. 2007, 39, 827-829. [CrossRef] [PubMed]

192. Liu, Y.; Helms, C.; Liao, W.; Zaba, L.C.; Duan, S.; Gardner, J.; Wise, C.; Miner, A.; Malloy, M.J.; Pullinger, C.R.; et al. A genome-wide association study of psoriasis and psoriatic arthritis identifies new disease loci. PLoS Genet. 2008, 4, e1000041. [CrossRef] [PubMed] 
193. Simpson, N.; Gatenby, P.A.; Wilson, A.; Malik, S.; Fulcher, D.A.; Tangye, S.G.; Manku, H.; Vyse, T.J.; Roncador, G.; Huttley, G.A.; et al. Expansion of circulating T cells resembling follicular helper T cells is a fixed phenotype that identifies a subset of severe systemic lupus erythematosus. Arthritis Rheum. 2010, 62, 234-244. [CrossRef] [PubMed]

194. McPhee, C.G.; Bubier, J.A.; Sproule, T.J.; Park, G.; Steinbuck, M.P.; Schott, W.H.; Christianson, G.J.; Morse, H.C.; Roopenian, D.C. IL-21 is a double-edged sword in the systemic lupus erythematosus-like disease of BXSB.Yaa mice. J. Immunol. Baltim. Md 1950 2013, 191, 4581-4588. [CrossRef] [PubMed]

195. Izui, S.; Ibnou-Zekri, N.; Fossati-Jimack, L.; Iwamoto, M. Lessons from BXSB and related mouse models. Int. Rev. Immunol. 2000, 19, 447-472. [CrossRef] [PubMed]

196. Herber, D.; Brown, T.P.; Liang, S.; Young, D.A.; Collins, M.; Dunussi-Joannopoulos, K. IL-21 has a pathogenic role in a lupus-prone mouse model and its blockade with IL-21R.Fc reduces disease progression. J. Immunol. Baltim. Md 1950 2007, 178, 3822-3830. [CrossRef] [PubMed]

197. McGuire, H.M.; Walters, S.; Vogelzang, A.; Lee, C.M.Y.; Webster, K.E.; Sprent, J.; Christ, D.; Grey, S.; King, C. Interleukin-21 is critically required in autoimmune and allogeneic responses to islet tissue in murine models. Diabetes 2011, 60, 867-875. [CrossRef] [PubMed]

198. Kwok, S.-K.; Cho, M.-L.; Park, M.-K.; Oh, H.-J.; Park, J.-S.; Her, Y.-M.; Lee, S.-Y.; Youn, J.; Ju, J.H.; Park, K.S.; et al. Interleukin-21 promotes osteoclastogenesis in humans with rheumatoid arthritis and in mice with collagen-induced arthritis. Arthritis Rheum. 2012, 64, 740-751. [CrossRef] [PubMed]

199. Erb, K.J.; Rüger, B.; von Brevern, M.; Ryffel, B.; Schimpl, A.; Rivett, K. Constitutive expression of interleukin (IL)-4 in vivo causes autoimmune-type disorders in mice. J. Exp. Med. 1997, 185, 329-339. [CrossRef] [PubMed]

200. Singh, R.R. IL-4 and many roads to lupuslike autoimmunity. Clin. Immunol. Orlando Fla 2003, 108, 73-79. [CrossRef]

201. Ma, J.; Zhu, C.; Ma, B.; Tian, J.; Baidoo, S.E.; Mao, C.; Wu, W.; Chen, J.; Tong, J.; Yang, M.; et al. Increased frequency of circulating follicular helper $\mathrm{T}$ cells in patients with rheumatoid arthritis. Clin. Dev. Immunol. 2012, 2012, 827480. [CrossRef] [PubMed]

202. Zivojinovic, S.; Pejnovic, N.; Sefik-Bukilica, M.; Kovacevic, L.; Soldatovic, I.; Bugarski, D.; Mojsilovic, S.; Damjanov, N. Effects of TNF inhibitor on innate inflammatory and Th17 cytokines in stimulated whole blood from rheumatoid arthritis patients. Inflammopharmacology 2012, 20, 323-330. [CrossRef] [PubMed]

203. Jang, E.; Cho, S.-H.; Park, H.; Paik, D.-J.; Kim, J.M.; Youn, J. A positive feedback loop of IL-21 signaling provoked by homeostatic $\mathrm{CD} 4^{+} \mathrm{CD} 25^{-} \mathrm{T}$ cell expansion is essential for the development of arthritis in autoimmune K/BxN mice. J. Immunol. Baltim. Md 1950 2009, 182, 4649-4656. [CrossRef] [PubMed]

204. Nishimoto, N.; Kishimoto, T. Inhibition of IL-6 for the treatment of inflammatory diseases. Curr. Opin. Pharmacol. 2004, 4, 386-391. [CrossRef] [PubMed]

(C) 2016 by the authors; licensee MDPI, Basel, Switzerland. This article is an open access article distributed under the terms and conditions of the Creative Commons by Attribution (CC-BY) license (http://creativecommons.org/licenses/by/4.0/). 